Review

\title{
Progress of Nanomaterials in Preventative and Restorative Dentistry
}

Supriya Rattan ${ }^{1,{ }^{\dagger}}$, Derek Fawcett ${ }^{1,{ }^{\dagger}}$, M. Tennant $2,{ }^{\dagger}$, Joanna Granich ${ }^{3,{ }^{\dagger}}$, Gerrard Eddy Jai Poinern ${ }^{1,}$ $+, *$

1. Murdoch Applied Nanotechnology Research Group. Department of Physics, Energy Studies and Nanotechnology, Murdoch University, Murdoch, Western Australia 6150, Australia; E-Mails: rattan3sm@yahoo.co.in; fawcett@southwest.com.au; g.poinern@murdoch.edu.au

2. Faculty of Science, School of Human Sciences, University of Western Australia; E-Mail: marc.tennant@uwa.edu.au

3. Telethon Kids Institute, University of Western Australia; E-Mail: Joanna.Granich@telethonkids.org.au

+ These authors contributed equally to this work.

* Correspondence: Gerrard Eddy Jai Poinern; E-Mail: g.poinern@murdoch.edu.au

Academic Editor: Hossein Hosseinkhani

Recent Progress in Materials

2021, volume 3, issue 1

doi:10.21926/rpm.2101007
Received: November 02, 2020

Accepted: February 19, 2021

Published: March 05, 2021

\begin{abstract}
To date, many studies have examined the development and use of novel materials, enhancing the performance of existing dental composites and improving methods for restoring tooth structure. In recent years, nanotechnology-based techniques have been used to develop a variety of nanomaterial-based dental products aimed at conservative dentistry applications. These new nanomaterial-based materials offer improved physicochemical and mechanical properties, combined with enhanced aesthetics that makes them superior restorative materials in several dental procedures. This review discusses tooth structure, the oral microbial environment, chronic dental diseases such as dental decay (or caries), and periodontal disease, as well as systemic diseases in light of nanotechnology-based preventative and restorative dental filler product advancements. Considerations regarding human health and safety associated with the use of nanomaterials in dentistry are discussed.
\end{abstract}

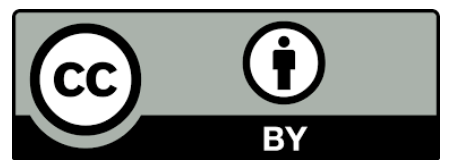

(C) 2021 by the author. This is an open access article distributed under the conditions of the Creative Commons by Attribution License, which permits unrestricted use, distribution, and reproduction in any medium or format, provided the original work is correctly cited. 
Lastly, knowledge gaps and limitations including future perspectives warranting further research are outlined. The study is followed by a conclusion which condenses the extensive data into a brief summary to establish a link between new nanomaterials and human interactions. This paper draws out and distils the current findings that have emerged from a substantial bibliographical review of a range of articles to provide an insight into the use and development of novel nanomaterials for preventive and restorative dentistry.

\section{Keywords}

Conservative dentistry; nanotechnology; nanomaterials; dental decay; caries and periodontal disease

\section{Introduction}

Historically, dental care procedures are believed to have started around 7,000 BC with holes being made in teeth to remove tooth decay [1]. Later the Sumerian's ( $\sim 5000 \mathrm{BC}$ ) explained the reason for tooth decay (or caries), with their manuscripts describing "tooth worms" as being the cause for tooth deterioration and decay. While ancient Egyptian texts from around 2500 BC reported the use of gold wire ligatures to stabilize loose teeth and prevent their loss [1]. Other early civilisation also made efforts to restore the function of diseased teeth. Both the Etruscans ( $500 \mathrm{BC}$ ) and the Phoenicians ( 300 AD) carved replacement teeth from materials such as oxen bones and ivory, and then using gold wire, fix the replacement in place $[2,3]$. While in the America, Mayans ( $600 \mathrm{AD}$ ) used carved shells and Honduran's civilisations ( $800 \mathrm{AD}$ ) used fashioned stone to replace mandibular teeth [4]. But it was not until the 18th century in Europe that dentistry became more scientific, with early dentists like Pierre Fauchard identifying acids and sugars as the drivers for dental decay. His studies also presented concepts such as repairing teeth with dental fillings, using teeth braces and dental implants. It was also during this period that teeth were collected from cadavers or the poor for use in patients. This practise continued for many years until the development of replacement porcelain teeth in the 19th century [2]. It was during the early part of the 20th century that significant and rapid developments in new materials and implants for dental applications emerged. And, by the middle of the century, the use of biocompatible metals such as stainless steel and cobalt-chromium-molybdenum were being extensively used. While during the second half of the century saw the use of titanium alloys in dental restorative procedures to return masticatory functions to patients [5, 6]. By the end of the 20th century, dental restorations were broadly classified into six categories, namely, filling materials, crowns, implants, bridges, dentures and Inlay or onlay restorations. All of these restoration procedures can be carried out by either direct or indirect methods. In direct restorations the damage is repaired, decayed tissue is removed and the cavity is filled with a suitable filler material in situ. While indirect restoration methods involve the fabrication of a replacement tooth or implant outside the patient's mouth, following a direct cemented replacement in the mouth during a subsequent visit.

However, it is interesting to note that while human kind has been grappling with dental issues for a long time and that despite many scientific developments and medical advancements, dental treatment is still needed today. Significantly, dental related diseases affect almost everyone at some 
stage of life [7]. In the UK alone, each child has on average 3 to 4 teeth affected by tooth decay and the average NHS cost of treating oral health conditions on children's dental care is about $\mathrm{f} 3.4$ billion per year [8]. Dental decay is increasingly recognized as a worldwide public health concern affecting mostly children in UK and US and is an ever-increasing burden to governmental and private health cost. In Australia, survey data showed that recurrent expenditure on dental services accounted to about \$8,706 million in 2012-13 [9]. These statistical highlights have clearly revealed the urgent need to address the importance of preventive and restorative strategies for better dental hygiene and practices.

A variety of traditional restorative materials (metals, polymers, ceramics and composites) are currently being used in dentistry across the world. These materials are expected to perform in a very hostile environment, in which $\mathrm{pH}$, salivary flow and mechanical loads rapidly fluctuate during day and night. Furthermore, in the treatment of dental caries, filler materials are not only expected to fill and seal the cavity, but are also expected to prevent further bacterial invasions, restore lost aesthetics, and preserve the remaining pulp and tooth structure [10]. However, in spite of the many advantageous physiochemical and mechanical properties of these materials, no material has yet proven to be ideal for all dental applications [11]. For example, traditional dental amalgams are composed of elemental mercury ( 42 to $50 \%$ ), silver ( 22 to $32 \%)$, tin (14\%) and copper (8\%) have been extensively used in dental restoration for over a century $[12,13]$. Importantly, their use in dental fillings is straightforward procedure and begins with the amalgam being mixed. Once mixed, the amalgam is packed into the prepared dental cavity where it sets and forms a hard filling with similar mechanical properties to the surrounding tooth. Unfortunately, toxicity studies carried out in the early 1980s revealed significant amounts of mercury leaching from amalgams. Subsequent patient blood tests by Abraham et al., revealed increased mercury levels in blood samples following mercury amalgam use $[14,15]$. This posed significant concern, since elevated mercury levels in the blood have been associated with certain diseases such as chronic fatigue syndrome and fibromyalgia [12]. Further amalgam toxicity research, revealed that modern amalgams tend to be less stable than more traditional amalgams, concluding that mercury vapour emission rates from modern amalgams were typically ten times higher [16]. This body of evidence for amalgam leaching resulted in the establishment of several anti-amalgam advocacy groups whom are lobbying governments globally to restrict or eliminate the use of amalgams in dental restoration, especially among children [17]. Another problem associated with the use of amalgams is the silver-grey colour. For consumers this is, not aesthetically pleasing. Thus, alternative materials are constantly being developed and evaluated as possible replacements for amalgams [18], such as composite resins. These polymers have emerged as more aesthetically appealing restorative materials. However, composite resin's restorative integrity is questionable with secondary caries rates between 50 to $60 \%[19,20]$ as a result of composite resin micro-leakage which typically forms at the interface between the prepared tooth cavity and the restorative resin [21]. This problem highlights the importance of selecting the most appropriate restorative material which is also dependent on patient factors such as age, size of cavity and the amount of viable tooth structure left after removal of a carious lesion, and the location of the cavity in the mouth [22-24]. Thus, not only does the restorative material have to restore aesthetics, function and morphology of tooth structure. It also needs to be biocompatible, capable of withstanding occlusal loads, prevent gap \& biofilm formations, promote remineralisation \& self-repair, and be easily applied during the restoration process [25]. At present no currently 
available synthetic biomaterial meets all of the abovementioned requirements for all dental applications [26, 27].

Nanotechnology-based manufacturing processes for producing nanomaterials with unique properties and structures has attracted considerable interest in recent years. Nanomaterials are characterised by their small size (a least on dimension less than $100 \mathrm{~nm}$ ) and having a large surface area to volume ratio [28]. They are also characterised by having large proportion of their atoms located near the surface and having large surface energies. Because of these unique features, nanomaterials have been introduced in several innovative dental applications in recent years. Some of these applications include nanometre scale resin-based composites and glass-ionomer nanocomposite cements $[29,30]$. Moreover, the natural mineral components of bone and tooth hard tissue materials are of nanometre scale units. Importantly, the demand for new dental biomaterials will ensure the continued development of new nanomaterials for standalone products or being incorporated into existing products to improve their performance [31, 32]. Ultimately the goal of new nanomaterials designed for restorative dentistry is to closely match the properties of oral tissues, thus ensuring the restoration fully restores the integrity of the oral tissues. Hence, if suitable nanomaterials are developed and used effectively in dental restorative procedures, major benefits can be achieved such as improved oral health, general wellbeing and an improved quality of life for patients. The aims of this review were to: 1 ) summarize the structure of human teeth; 2 ) describe oral microbial homeostasis and oral health in terms of dental caries, periodontal diseases, and systematic diseases; 3 ) outline nanotechnology-based preventative and restorative dental filler materials being resin based composites, glass-ionomer cements and calcium phosphates, including hydroxyapatite; 4) discuss potential health and safety risks associated with the use of nanomaterials in dentistry, and finally, (5) discuss future perspectives, knowledge gaps and suggestions for future research.

\section{Human Teeth and Their Structure}

The oral cavity contains teeth, salivary glands and tongue, which contribute to the mechanical mastication and initial chemical digestion of food. Like bone, teeth are a rigid and hard form of connective tissue that is classified as hard tissue. The unique structure and composition of teeth endows them with exceptional mechanical properties that enable them to perform the demanding functions of incision, laceration and grinding. During mastication teeth function in a very hostile environment, in which saliva flow, $\mathrm{pH}$, and various mechanical forces (flexural and shear) and various force combinations constantly and rapidly change. To assist in transferring the mechanical forces of mastication, the teeth are anchored in sockets (alveoli) in the gum-covered boundaries of the mandible (lower) and maxilla (upper) jaw bones. Each tooth has two distinct regions (crown and root) (see Figure 1), which are delineated by the gum. The first region is the upper enamel-coated crown, which is above the gum and directly experiences the tearing and grinding of food during mastication. The thin $(<1 \mathrm{~mm})$ enamel coating is acellular, highly mineralised, brittle and the hardest material in the human body. It is composed of inorganic materials ( $96 \%$ wt.), with the balance of the weight made up by organic materials and water. The enamel microstructure consists of rod-like structures that are typically $5 \mu \mathrm{m}$ in diameter. These rod-like structures are composed of densely packed hydroxyapatite crystals ( $26 \mathrm{~nm}$ in diameter and $68 \mathrm{~nm}$ in length) surrounded by a 2 $\mathrm{nm}$ thick layer of protein [33]. The rod-like structures are also perpendicularly orientated to the 
tooth surface to resist forces resulting from mastication [34]. Thus, giving the enamel an anisotropic force resisting property. Importantly, soon after the tooth erupts from the gum, the cells responsible for generating the enamel coating soon disintegrate. Thus, the resulting acellular enamel is unable to heal itself from damage or decay and must undergo restorative dental procedures to restore structural integrity, if damaged or removed.

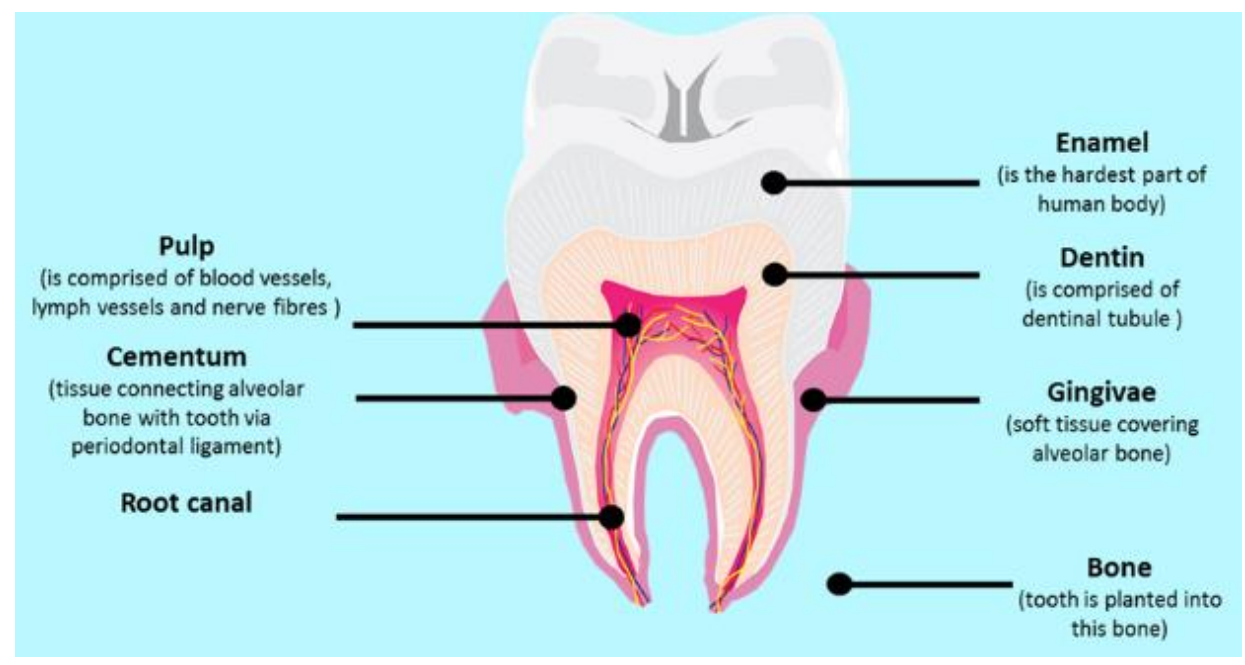

Figure 1 An illustration of a healthy tooth dissected lengthways to show the internal layers and structures forming the crown and root.

The second and lower region of the tooth embedded in the gum and underlining bone is the cementum covered root (see Figure 1). The cementum coating has similar properties to bone tissue and is also composed of calcium containing apatites that form the inorganic phase, while collagen and non-collagen proteins form the organic phase. Importantly, the cementum attaches to the surrounding thin periodontal ligament to form a tight collar within the alveoli [35]. Also present, underlying and supporting the enamel in the crown and the cementum in the root is the bone-like dentine, which forms the bulk of the tooth. Dentine is less mineralised (65-70\%) than enamel (96\%), but more mineralised than the cementum (45-50\%). Dentine is not as hard as enamel, but is harder than the cementum. The inner most region of dentine contains the central pulp cavity, which contains blood vessels, connective tissue and nerve fibres. Also present and radiating outwards from the central pulp cavity to the exterior cementum or enamel coating are micro-scale liquid filled tubules. Each tubule contains an odontoblast cell that generates and maintains the dentine [36].

It is the composition and complicated structure of teeth that directly influences its amazing mechanical properties. These properties include elasticity, hardness, fracture toughness and viscoelasticity. Tooth elasticity is its ability to recover its original dimensions after external forces are removed during mastication. While tooth hardness is an indicator of its ability to withstand elastic deformation, plastic deformation and destruction [34]. An important property of a tooth is its fracture toughness, which determines its strength and the growth rate of cracks resulting from fatigue and age [37]. Whereas, very few viscoelasticity studies have evaluated teeth and those that did have focused on the dynamic mechanical properties of dentine [38]. To date, elasticity and hardness are the two most studied mechanical properties of teeth. In particular both enamel and dentine have been extensively studied, while cementum has been studied to a lesser extent [38-40]. Moreover, earlier studies assumed tooth composition and structure were isotropic in nature and 
both elasticity and hardness were the same in all directions. However, in recent years, with a greater understanding of factors such as mineral and organic component densities, rod arrangements in the enamel, the direction of tubules and organic fibres in the dentine, the tooth structure was found to be highly anisotropic in nature [37, 41,42]. For instance, the anisotropic nature of enamel and its influence on elasticity and hardness has been found to vary with respect to the directions of the enamel rods, calcium content and gradually decrease from the surface to the enamel-dentine interface $[43,44]$. In addition, dentine elasticity and hardness is not only closely related to its complex structure and composition, but also to the external environment. In terms of composition, highly mineralised dentine can have an elastic modulus between 40 and $42 \mathrm{GPa}$, while poorly mineralised dentine can have modulus values as low as $17 \mathrm{GPa}$ [45]. In terms of external environmental factors, studies have shown dentine is isotropic in a dry environment and anisotropic in a moist environment. For instance, in a hydrated environment, elasticity and hardness both decrease by $35 \%$ and $30 \%$ respectively $[46,47]$. The mechanical and thermal properties of human teeth are presented in Table 1, along with typical elasticity and hardness values reported by several researchers for enamel and dentine. It must be pointed out that current dental restorative materials have not been able to fully reproduce the complicated structure and unique mechanical properties of human teeth. Moreover, restoration failure generally results from a combination of factors such as inappropriate dental material composition, poor material properties and bacterial growth on dental surfaces. Crucially, the oral microbial environment has an important role in sustaining oral health and assisting in preserving dental restorations [10]. Emerging data of the oral microbiome's role where there can be up to 1000 species [48] can colonise the oral cavity shows a much more complex interaction of these species with the underlying material of the tooth as well as the surrounding tissues and support structures. Figure 2 shows the optical images of extracted human tooth at different angles or positions.

Table $1 \mathrm{~A}$ selection of mechanical and thermal properties of several dental materials.

\begin{tabular}{|c|c|c|c|c|c|}
\hline \multirow[t]{2}{*}{ Material } & \multicolumn{2}{|c|}{ Mechanical Properties } & \multirow[t]{2}{*}{ Ref. } & Thermal Property & \multirow[t]{2}{*}{ Ref } \\
\hline & Hardness (GPa) & $\begin{array}{l}\text { Elastic Mod. (G } \\
P a)\end{array}$ & & $\begin{array}{l}\text { Linear coefficients of } \\
\text { thermal expansion 20- } \\
60^{\circ} \mathrm{C}(\mathrm{ppm})\end{array}$ & \\
\hline & Surface & 60 to 100 & {$[49]$} & 11.4 & [50] \\
\hline Enamel & $5 \pm 0.45$ & & & & \\
\hline (Premolar) & $\begin{array}{l}\text { Cross-section } \\
4.5 \pm 0.45\end{array}$ & 40 to 80 & {$[34]$} & - & - \\
\hline & Pulp wall & Pulp wall & {$[51]$} & & \\
\hline & $0.52 \pm 0.24$ & $11.59 \pm 3.95$ & & 8.3 & {$[52]$} \\
\hline Dentine & Middle area & Middle area & & & \\
\hline Crown of & $0.85 \pm 0.19$ & $17.06 \pm 3.09$ & [51] & & \\
\hline $1^{\text {St }}$ Molar & $\begin{array}{l}\text { Dentin-enamel } \\
\text { Junction } \\
0.91 \pm 0.15\end{array}$ & $\begin{array}{l}\text { Dentin-enamel } \\
\text { junction } \\
16.33 \pm 3.83\end{array}$ & {$[51]$} & & \\
\hline Ag amalgam & $2.34 \pm 0.27$ & $107.00 \pm 12.00$ & [53] & $22.1-28.0$ & {$[52]$} \\
\hline Porcelain & 5.5 to 6.5 & 55 to 75 & {$[54]$} & 12.0 & [52] \\
\hline
\end{tabular}




\begin{tabular}{llllll}
$\begin{array}{l}\text { Glass-ionomer } \\
\text { cement }\end{array}$ & $0.7 \pm 0.02$ & $4.5 \pm 0.3$ & {$[55]$} & $10.2-11.4$ & [52] \\
$\begin{array}{l}\text { Resin } \\
\text { Nanocomposite }\end{array}$ & $1.2 \pm 0.1$ & $16.0 \pm 1.1$ & {$[56]$} & $14-50$ & [57] \\
Nanocomposite & $0.2 \pm 0.01$ & $8.5 \pm 2.0$ & {$[58]$} & - & - \\
\hline
\end{tabular}

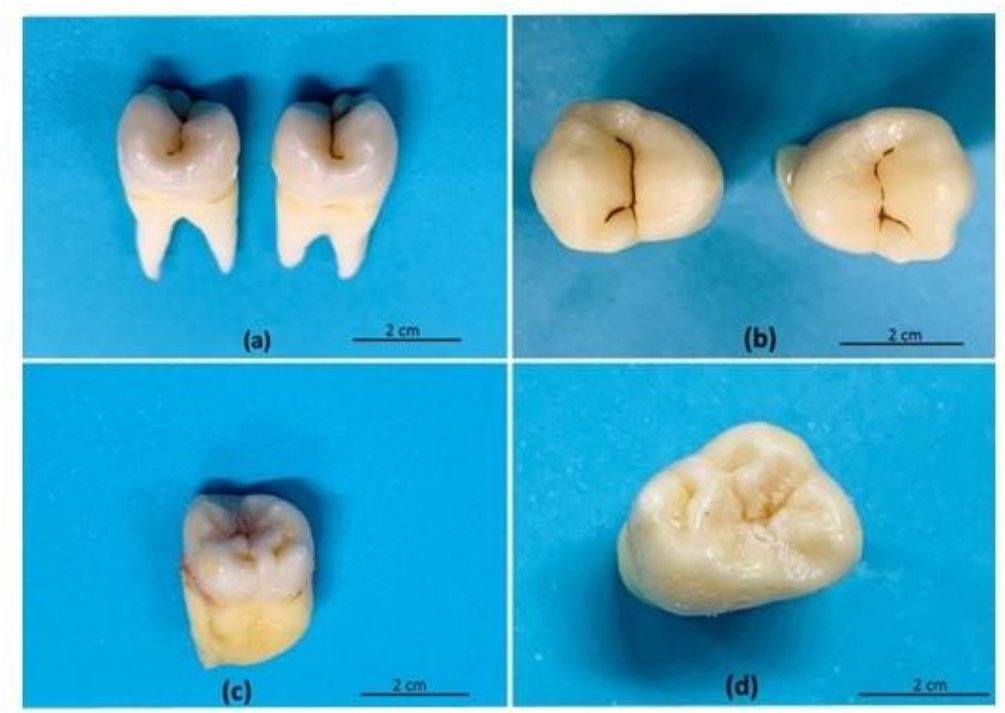

Figure 2 Optical images of human teeth: (a) lingual view of extracted and bleached wisdom tooth; (b) occlusal view of extracted and bleached wisdom tooth with visible cavities in cusp regions; (c) lingual view of extracted healthy wisdom tooth sample, and (d) occlusal view of extracted healthy wisdom tooth with no visible cavities.

\section{Oral Cavity Environment}

Humans are not only composed of their own diverse range of cells, but they are also heavily colonised by a wide variety of microorganisms. These microorganisms live either in or on the surface of the body and their numbers can be more than ten times greater than the number of cells forming the body [59]. Figure 3 represents the site of attachment of different microbial colonies at various structural receptors present on tooth surfaces. The microbial communities found in the oral cavity are considered the second most complex in the body, the first being the colon [60]. The highly diverse oral microbiome contains around 700 species composed of archaea, bacteria, fungi, protozoa and viruses [61]. The presence of microorganisms in the oral cavity is a natural and normal occurrence in the mouth [62]. But unlike commensal microorganisms found in other parts of the body such as the colon, which assist the body in fighting pathogens, help regulate the immune system and maintain homeostasis, the microbiota of the mouth are also actively involved in pathogenesis and promote many oral and systemic diseases [63, 64]. Examination of early human remains $(\sim 7,000 \mathrm{BC})$ has shown the presence of manmade holes in teeth to remove tooth decay. And recent bio-molecular studies of these ancient adult teeth and skeletons has confirmed the mouth cavity acted as a reservoir for microbial organisms involved in both oral and systemic diseases [65]. In particular, microbial organisms have a strong tendency to attach and colonise the various tissue surfaces found within the oral cavity $[66,67]$. The oral cavity contains soft tissue surfaces (oral mucosa and tongue), hard tissue surfaces (teeth), and saliva [68]. Importantly, 
microbial attachment and colonisation is influenced by the interplay of several favourable and unfavourable factors. And regardless of favourable factors such as suitable tissue surface chemistry, nutrients, temperature and humidity, microbial colonisation is constantly being challenged by the body's immune system $[69,70]$. However, it should be pointed out that the presence of commensal microbes in the mouth is an important factor in preventing colonisation by pathogens. Colonising commensal microbes achieve this by reducing the number of available binding sites for pathogens [71]. For instance, in vitro studies have shown microbes such as Streptococcus salivarius (strain K12) inhibit the growth of several pathogenic species associated with periodontitis and halitosis [72, 73]. This ecological balance can be readily seen when antimicrobial agents disrupt the balance and opportunistic pathogens infect the oral tissues [74]. Thus, highlighting the importance of commensal microbes being present and the importance of maintaining an ecological balance for preserving a healthy oral environment [63]. However, studies have shown commensal microbes are site specific [75, 76]. For instance, soft tissue surfaces such as the cheek and palate have a monolayer of bacteria. The tongue has multiple coatings of microbes that also include bacteria. Crypts present in the tongue provide an ideal environment for anaerobic microbes to thrive [77, 78]. While the continuously flowing saliva has a similar microbial profile to both tissues surfaces and biofilms. The major part of the microbial content present in saliva is produced by biofilm flaking from oral tissues $[79,80]$. The viscous properties of saliva also assist in rinsing the teeth and soft tissues, and also assists in microbe desorption from the teeth and soft tissues [81, 82]. In addition, the saliva also contains chemicals such as bicarbonate and calcium phosphate that are used to buffer the effects of acids produced from the consumption of food and drink and/or bacterial metabolism [83]. Thus, the saliva neutralises the effects of generated acids, prevents acid erosion of the teeth and maintains oral cavity $\mathrm{pH}[84,85]$. Also present in saliva are antimicrobial proteins for instance lysozyme and lactoferrin, as well as immune system components such as immunoglobulins that also promote a healthy oral environment. Furthermore, studies have shown that salivary microbiota can be used as diagnostic indicators for several diseases like dental caries, periodontitis and oral cancer [86, 87].

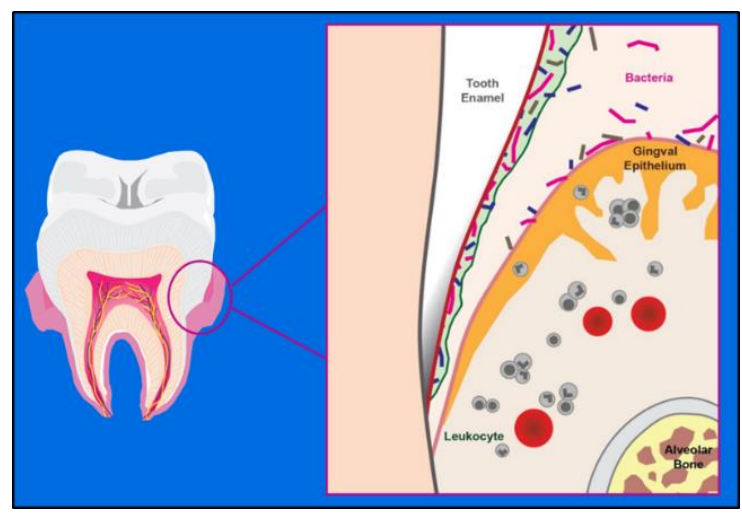

Figure 3 A diagrammatic representation of tooth and surrounding gum tissue in the oral cavity with microbial colonization present at the enamel-gum interface.

The most distinctive feature of the mouth is the array of teeth. The non-shedding hard tissue surfaces that form each tooth can provide a stable location for microbial colonisation [88]. In addition, both microbe surfaces and tooth surfaces are negatively charged. This results in the soluble cations (potassium, sodium, magnesium and calcium) present in saliva being attracted to 
the negatively charged surfaces. This results in the generation of a double charged layer (electrical double layer) forming around the respective surfaces that produce a repulsive electrostatic force. Meanwhile, microbes approaching tooth surfaces also experience a repulsive force (van der Waals force). The resulting modulation between the two interacting electrostatic forces generate equilibrium and subsequently promotes the attachment of microbes to tooth surfaces [89, 90]. In addition, exposure to saliva produces a proteinaceous coating on tooth surfaces called the pellicle. The pellicle layer is composed by amino acids, amylase, glucose, glycosyltransferases, muscin, lysozyme, and soluble ions [91, 92]. The pellicle moderates surface charge and promotes attractive interactions between the tooth and oral environment [93]. Thus, microbes are able to attach to the pellicle through adhesin-receptor interactions and colonise the tooth surface to form a biofilm. The biofilm, known as dental plaque, is a functionally organised structure resulting from the metabolic interactions occurring between different microbial species forming the colonising community [94]. There are two types of dental plaque. Above the gum line, it is known as supra-gingival plaque and below the gum line it is known as sub-gingival plaque. Supra-gingival plaque is linked to tooth decay and promotes the formation of dental caries. Clinical studies have shown the number of caries increase with growing numbers of acidogenic and aciduric (acid-tolerating) bacteria such as Streptococci mutans and lactobacilli, which are constituent members of plaque $[95,96]$. Numbers of these acid-tolerating bacteria can rapidly increase when acidic by-products produced from their metabolism of fermentable carbohydrates, reduces oral $\mathrm{pH}$ levels and promotes their proliferation $[97,98]$. Meanwhile, the under lower $\mathrm{pH}$ levels reduce the survival rates of acidic sensitive microbial species that promote good tooth health $[99,100]$. Also, the lower $\mathrm{pH}$ levels produce higher tooth dissolution rates. While below the gum line sub-gingival plaque extends down along the tooth root. In this region there is very little saliva and local $\mathrm{pH}$ levels and temperatures are more severe, and the local environment becomes more anaerobic [82]. Common to both types of plaque is their degree of stability (microbial homeostasis) achieved by their respective microbial communities [101]. Apart from regular events like dietary intake and oral hygiene, microbial homeostasis is achieved by balancing the numerous synergic and antagonistic interactions occurring between the various members of the microbial community $[102,103]$.

\section{Oral Microbial Homeostasis and Health}

The interactions occurring between oral microbiota and the host are extremely important in maintaining good oral and systemic health. Many of these microbes have evolved unique biological characteristics and properties that are antagonistic to many oral pathogens, which makes them beneficial for good health and wellbeing. These biological characteristics and properties are important factors in controlling microbial populations in the oral cavity [71]. For instance, in vitro studies by Wescombe et al., showed that bacteriocin produced by Streptococcus salivarius (strain K12) inhibits several detrimental microbial species associated with periodontitis and halitosis [72, 104]. But the role of these factors is complex, since signalling molecules not only modulate and influence the activity of microbial species, they also interact with the immune system [105-107]. Importantly, because biofilms are in extremely close physical contact, they have the greatest opportunity to interact with oral tissues and in turn interact with the immune system [108]. Several studies have shown dental decay is not restricted to a single species, but is the outcome of interactions occurring between various microbial species and oral tissues that result in virulence 
and pathogenesis [109-111]. Crucially, these interactions regulate microbial homeostasis, but when out of balance can drive the pathogenic potential of cariogenic microbial species. Hence, the following subsections briefly discuss major oral and systemic diseases associated with oral microbiota.

\subsection{Dental Caries}

When microbial homeostasis is disturbed the character of dental plaque changes. One major disturbance is the ingestion of high levels of fermentable carbohydrates and sugars on a regular basis. This leads to higher acid production levels, lower salivary buffering and lower pH levels [95]. Acidification results in a series of complex interactions occurring between acid-producing bacteria and fermentable carbohydrates. These interactions result in major changes to the phenotypic and genotypic composition of the plaque and leads to the formation caries [112]. Dental caries is the most common form of oral disease that results in pain and subsequent tooth loss [94]. Figure 4 outlines the different stages of dental caries, when the process is initiated by growth of bacterial biofilm which gradually dissolves the enamel, followed by dentine and pulp. Importantly, acidification favours aciduric microbial species that are better able to adapt to lower oral pH levels $[113,114]$. In particular, species such as Streptococcus mutans and lactobacilli thrive in acidic conditions and are considered pathogens because of their cariogenic properties [115, 116]. Studies have also reported species like Actinomyces spp., Atopobium spp., Bifidobacterium, Propionibacterium and Scardovia are also involved in caries formation [96, 117-119]. Importantly, these studies have shown that dental caries are caused by the interactions of a complex community rather than a single pathogen [81]. Also present are bacterial species that can raise the $\mathrm{pH}$ level by producing ammonia from arginine and urea molecules [99]. The alkalising effect not only raises $\mathrm{pH}$ levels, but also assists in balancing acid production from dietary carbohydrates and sugars, and supports microbial homeostasis. Importantly, alkali production moderating the effects of dental decay and provides some degree of protection against dental caries [94, 99]. Crucially, if dental caries is not treated, decay progresses through the dentine towards the root canal and pulp. On reaching the pulp, the pulp becomes infected and subsequently dies resulting in tooth extraction [120].

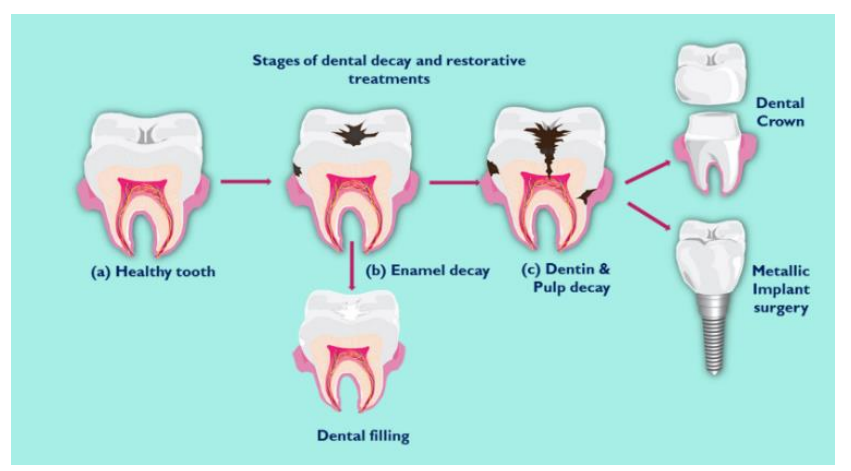

Figure 4 Illustration of different stages of tooth decay progression and dental restoration strategies. (a) A representation of tooth with no visible decay, (b) decay of the enamel and is generally sealed by filling with a dental filler material, (c) decay has spread to the dentine and pulp, accompanied by tooth pains and this condition is either cemented with a new crown or fixed with a metallic implant. 


\subsection{Periodontal Diseases}

The most common periodontal disease of humans is gingivitis and its prevalence in the adult population can be as large as $90 \%$ [121]. Dental plaque constantly forms on all tooth surfaces. But with increasing numbers of gram-negative and anaerobic microbial species in plaque located at the gingival boundary, there is a transfer of endotoxins and other enzymes into the gingivae [122]. This contamination results in an inflammatory response and the gingivae becomes inflamed and swollen. Species like Haemophilus, Lautropia, Leptotrichia, Prevotella, Streptococcus and Veillonella have been closely associated with gingivitis [123, 124]. Gingivitis can be reversed or prevented altogether by regular tooth cleaning, which significantly reduces plaque levels on teeth. However, if oral hygiene is not practiced, plaque levels increases and the severity of the disease increases [123, 125]. In extreme cases, gingivitis produces destructive inflammation and results in the bone loss disease known as periodontitis. Unlike gingivitis, periodontitis is a chronic and irreversible inflammatory disease that results in the destruction of alveolar and connective tissue in the jaws [126].

\subsection{Oral and Systematic Diseases}

The oral microbial community has long been known as a source of both oral and systematic infections. One common mucosal disease of the mouth, which is characterised by painful ulcers is recurrent aphthous stomatitis (RAS). Studies have shown that RAS is linked with specific microbial species present in both mucosal and salivary microbiota $[127,128]$. Studies have also linked oral microbiota with oral cancer, but the mechanisms involved are currently not fully understood to date $[129,130]$. For instance, oral squamous cell carcinoma (OSCC) studies of the mouth epidermis tissues found the surface of carcinoma cells had significantly higher numbers of aerobes and anaerobes than healthy cells $[131,132]$. The role of bacteria in cancer has been reported for several years. Researchers believe the presence of bacteria and their secretions provokes inflammatory responses that influence cell proliferation, mutagenesis, oncogene activation and angiogenesis [130, $133,134]$. Because of this association, recent research has focused on identifying specific oral microbiome as a new biomarker for detecting cancers [135]. Importantly, oral microbiome can gain access to the bloodstream through carious lesions and the gingival crevice. Once in the bloodstream, oral microbiome can circulate and infect various locations within the body. For instance, periodontal pathogens have been linked to cardiovascular diseases [136, 137], while oral microbiome have been detected in brain and liver abscesses [138-140]. Studies have also examined the relationship between periodontitis and diabetes, since badly controlled diabetes also contributes to periodontitis [141]. In addition, some studies have found no significant differences in microbial numbers present in saliva and sub-gingival plaques between diabetic and non-diabetic patients, while other studies have seen significant differences $[142,143]$. While recent studies have linked oral microbiome with diseases such as pancreatic and gastrointestinal cancers [144, 145]. Similarly, head and neck squamous cell carcinoma [146], as well as esophageal cancers [147] have also been linked to the presence of oral bacteria. The abovementioned studies clearly highlight the importance of maintaining an effective oral microbiome balance to sustain good human health and longevity. 


\section{Nanotechnology-Based Preventative and Restorative Dentistry}

In recent years nanotechnology-based techniques for manufacturing a variety of nanometre scale materials has attracted considerable interest due to the unique structures and properties displayed by these new nanomaterials. The tooth is essentially composed of nanomaterials that make up the enamel, dentine, and cementum. Accordingly, recent studies have focused on understanding the physiochemical and mechanical properties of nanomaterials for potential use in the field of dentistry [148, 149]. The two fundamental fields of dentistry are preventative and restorative. The objective of preventive dentistry is to inhibit or minimise risks of onset of dental diseases by which plaque removal through mechanical and behavioural management aids in early prevention of tooth decay and periodontal disease. To this end several nanomaterials have been included in a variety of oral health-care products such as toothpastes, mouth pastes and liquids in recent years [150]. While the objective of restorative dentistry is to use dental materials to replace tooth structure or oral (gingivae and bone) tissues resulting from disease processes, and to restore physical and mechanical functioning of the oral cavity [151, 152]. The inclusion of nanomaterials in both preventative and restorative dental procedures in the future is expected to improve oral health and benefit across the life-span of the patients.

\subsection{Preventive Dentistry}

Diseases occurring in the oral cavity are complex in nature. Thus, the main strategy of dental and health organisations is prevention. The most frequent disease found in the oral cavity is dental caries. And in spite of the surface pellicle, erosion and demineralization of tooth enamel takes place $[153,154]$. Also, the frequent consumption of acidic foods and beverages common in today's diets significantly accelerates enamel erosion and demineralization [155]. Further erosion and demineralization takes place if stomach acid reflux occurs after meals. To counter demineralisation and reduce dental decay, fluoride (re-mineralising agent) has been added to dental products [156, 157] and drinking water for many years $[112,158]$. The World Health Organisation (WHO) recommends the maximum permissible fluoride concentration in drinking water should not exceed $1.5 \mathrm{mg} / \mathrm{L}$ [159]. However, concentrations exceeding the maximum permissible concentration leads to serious health problems such as skeletal fluorosis [159].

The daily use of mouthwashes and toothpastes by patients is an important strategy to manage their oral health and help prevent the formation of both carious lesions and periodontal disease [160]. In medicine, nanomaterials are used in a variety of applications such as drug delivery, diagnostics and imaging tools [161, 162]. Accordingly, there has also been considerable interest in using nanotechnology-based methods to produce new dental products and improve the performance of traditional dental products [162, 163]. Nanotechnology-based products have the potential to improve the mineralisation of hard dental tissues using nanomaterials composed of hydroxyapatite and fluoride. While antimicrobial nanomaterials such as silver, zinc oxide and titanium oxide also have the potential to manage plaque and dental infections [27, 164, 165]. For example, the use of toothpastes and mouthwash preparations containing nanomaterials are effective strategy for mineralising tooth enamel and dentine, while also controlling microbes and plaque. In particular, studies have shown the inclusion of nano-hydroxyapatite in toothpaste can both enhance remineralisation and improve the hardness of tooth enamel and dentine $[165,166]$. 
This is achieved due to the extremely small size of nano-hydroxyapatite particles, which can readily enter and interact with sub-micrometre and nanometre scale damage on tooth surfaces caused by acidic erosion (white spots) [167]. During the interaction, calcium and phosphate ions are released from the nano-hydroxyapatite particles. The released ions move into the enamel rods and change into apatite crystals. Hence, re-mineralising and repairing enamel surfaces [168, 169]. Furthermore, several studies have shown the use of nano-hydroxyapatite in dental products can also lower bacterial colonisation of tooth surfaces and reduce dentine hypersensitivity [149, 170, 171].

In recent years, several manufacturers have produced a wide range of commercially available oral health-care products (liquids and pastes) for plaque management and re-mineralization of early sub-micrometre-scale enamel lesions as a method of preventing tooth decay. Products such as GC Tooth Mousse, MI Paste and Recaldant ${ }^{\circledast}$ each containing milk based casein phosphopeptides (CPP) and amorphous calcium phosphate (ACP) have been on the market for several years. In CPP-ACP based products, CPP combines with ACP to form amorphous nano-complexes that contain a rich source of stabilised calcium and phosphate ions [172]. On entering the oral acidic environment the nano-complexes dissociate, releasing calcium and phosphate ions for enamel remineralisation [173, 174]. Studies have also shown products such as Recaldant ${ }^{\circledR}$ exhibit anti-cariogenic properties and have been used to treat dentine hypersensitivity [175-179]. While a study by Reynolds et al., found the addition of fluoride into CPP-ACP pastes could significantly improve tooth re-mineralisation [174]. Alternatively, other manufacturers have used different active materials and approaches for controlling plaque and re-mineralising damaged enamel surfaces. Some of these alternative ingredients and products include sodium fluoride (PreviDent ${ }^{\circ}$ ), calcium sodium phosphosilicate (NovaMin ${ }^{\oplus}$ ), and arginine bicarbonates and calcium carbonates (SensiStat ${ }^{\oplus}$ ). A selection of currently available oral health-care products and their active ingredients is presented in Table 2.

Table 2 Commercially available calcium phosphate based toothpastes and dental creams.

\begin{tabular}{|c|c|c|c|}
\hline $\begin{array}{l}\text { Commercial } \\
\text { Name }\end{array}$ & Manufacturer & Active Ingredients & Description \\
\hline PreviDent $^{\circledast}$ & $\begin{array}{l}\text { Colgate Oral } \\
\text { Pharmaceuticals } \\
\text { (USA) }\end{array}$ & $\begin{array}{l}\text { Sodium Fluoride, Potassium } \\
\text { Nitrate, hydrated Silica, sorbitol, } \\
\text { PEG-12, Sodium lauryl sulfate, } \\
\text { titanium dioxide, sodium } \\
\text { saccharin, sodium hydroxide, } \\
\text { mica }\end{array}$ & $\begin{array}{l}\text { Prescription strength } \\
\text { fluoride toothpaste } \\
\text { for sensitive teeth }\end{array}$ \\
\hline $\begin{array}{l}\text { Regenerate }^{\circledR} \\
\text { Enamel } \\
\text { Science }\end{array}$ & Unilever, (UK) & $\begin{array}{l}\text { Glycerin, calcium silicate, PEG-8, } \\
\text { Hydrated silica, tri-sodium } \\
\text { phosphate, sodium phosphate, } \\
\text { PE-60, sodium laurly sulfate, } \\
\text { sodium mnofluorophosphate, } \\
\text { synthetic, fluorphlogopite, } \\
\text { sodium saccharin, polyacrylic } \\
\text { acid, tin oxide,limonene }\end{array}$ & $\begin{array}{l}\text { A patented } \mathrm{NR}^{\circledR} 5^{\circledR} \\
\text { technology using } \\
\text { calcium silicate and } \\
\text { sodium phosphate as } \\
\text { a combination to } \\
\text { form crystal } \\
\text { structures similar to } \\
\text { that of } \\
\text { hydroxyapatite. }\end{array}$ \\
\hline
\end{tabular}


MI Paste, MI GC AMERICA inc. Calcium Phosphopeptide (CPP), Paste Plus (USA)

Moothpaste MOOGOO

(Australia)

Arm

$\&$

Hammer $^{\circledR}$

dental range

$$
\begin{aligned}
& \text { Church \& Dwight } \\
& \text { Co., Inc. (USA) }
\end{aligned}
$$

Amorphous calcium phosphate

(ACP), glycerol, D-sorbitol, propylene glycol, silicon dioxide, titanium dioxide, phosphoric acid, zinc oxide, sodium saccharin, magnesium oxide, hydroxybenzoates

\section{Calcium}

carbonate,

hydroxyapatite, sodium-N-

lauroysarcosinate, glyceryl dioxide, triclosan

Sodi bicarbonate, glycine, PEG-8, hydrated silica, calcium sulfate,

$\begin{array}{clr}\text { Enamel Pro }^{\circledR} & \text { Premier Dental } \\ & \text { Products Co., } \\ & \text { (USA) }\end{array}$

NovaMin ${ }^{\circledR}$

SensiStat ${ }^{\circledR} \quad$ Ortek

Therapeutics

(USA) (UK)

(UK)

\section{G} caprylate, Anisic acid, titanium sodium lauryl sulfate, dipotassium phosphate, sodium carbonate, titanium dioxide

Fumed silica, sodium fluoride,

A gel or paste preparation used as a cleaning and polishing procedures by professionals. Variants available with ACP tech.

Contains NovaMin ${ }^{\circledR}$ $\begin{array}{ll}\text { Sodium } & \text { Phosphosilicate } \\ \text { (NOVAMIN), } & \text { Cocamidopropyl }\end{array}$

, PEG-8, Silica, Calcium Betaine, Sodium Methyl Cocoyl
Taurate, Sodium
Monofluorophosphate, technology i.e. Bioactive glass as an active abrasive to repair vulnerable Titanium Dioxide, Carbomer, Saccharin Sodium, Limonene. Arginine bicarbonate, calcium carbonate

A saliva based
composition to re-
mineralize teeth and
reduce dentinal
sensitivity

Another important function of several oral health-care products is to mediate and treat dentine hypersensitivity. Hypersensitivity results from the movement of oral fluid through the dentinal tubules and stimulating the nerves in the pulp. Bio-compatible nanomaterials such as nanohydroxyapatite, bioactive glass nanoparticles, calcium-based and arginine-based compounds have 
been incorporated in several products as a method of blocking the dentinal tubules and prevent tubule infiltration $[180,181]$. For instance, Novamin ${ }^{\circledR}$ contains bioactive glass particles (composed of calcium sodium phosphosilicate), which interact with the aqueous oral environment to releases calcium and phosphate ions. These ions combine to form a layer of hydroxyl-carbonate apatite crystallites that block the dentinal tubules [182, 183]. Other features of Novamin include antigingivitis properties and moderating plaque formation [184]. Unfortunately, the complex organic and inorganic structure of dentine makes re-mineralisation difficult. For instance, a study by Vollenweider et al., found treating dentine with ultrafine bioactive glass particles could not regain its original properties [185]. Similarly, a study by Shibata et al., also found the original mechanical properties of dentine could not be regained after treatment with colloidal nano-beta-tri-calcium phosphate [186]. While products such as ProClude ${ }^{\circledR}$ and SensiStat ${ }^{\circledR}$, which are composed of arginine, bicarbonate and calcium carbonate provide an alternative method for treating hypersensitivity. In the oral cavity the positively charged arginine combines with calcium carbonate to form a positively charged clusters. These clusters soon attach to the negatively charged dentine surfaces and in the process block the dentine tubules [187]. While another arginine-based product developed by Colgate is Pro-Argin ${ }^{\circledR}$, which also includes fluoride to enhance re-mineralisation as well as treating hypersensitivity [156]. In spite of these advanced oral health-care products, hard brushing hypersensitive teeth opens dentine tubules and produces erosion. And combined with a complex organic/inorganic structure, makes the treatment of hypersensitivity and re-mineralisation problematic and challenging $[183,188]$.

\subsection{Dental Fillers}

The use of dental fillers is one of the most common dental materials that are used for restorative procedures performed on humans. Traditionally, dentistry has used a variety of amalgams to replace lost tooth tissue in order to restore mechanical function. However, to date no material has been found that completely replicates the properties of natural teeth. For instance, in spite of being used for more than a century there are serious health concerns regarding the release of mercury ions from amalgams [18, 189]. And although being initially successful, dental materials are challenged continuously by recurrent caries that ultimately leads to their failure [190]. With failures levels resulting from secondary caries being as large as 50 to $60 \%$ for many dental materials [191, 192]. The high failure rates result from factors such as: 1 ) modelling the dental material to fit the prepared tooth cavity; 2 ) poor sealing between dental material and cavity wall, resulting in microleakage; 3) material deterioration over time; 4) material discolouration over the life of the restoration, and 5) tooth sensitivity after the restoration procedure [21, 193]. Because of these factors there has been extensive research into developing new dental composites with improved material properties [194]. Many current dental composites have similar mechanical properties to amalgams and also have desirable aesthetic properties $[195,196]$.

\subsubsection{Resin Based Composites}

Dental resin-based composites are a mixture of different materials. The reason for the mixture is that no single material can provide all the properties necessary for a successful dental restoration. Contemporary composites are a mixture of glycidyl methacrylate resin, which acts as the matrix polymer, and materials such as quartz, glass and silica act as fillers [197]. These mixtures also contain 
additives like polymerization initiators, accelerators and coupling agent (usually silane), which are designed to promote chemical bonding with the methacrylate matrix during polymerisation [198]. Also added are colouring pigments to produce aesthetically pleasing colours that closely match individual patient tooth colours. The mixture is then sculptured to fit the prepared tooth cavity. In early composite formulations, polymerisation was thermo-chemically initiated with initiators such as benzoyl peroxide. In contemporary composite formulations, the setting reaction is light activated by a lamp [199]. For a successful restoration, a dental composite must have the following features: 1) low viscosity to enable it to fill the prepared tooth cavity; 2 ) a controllable polymerisation rate; 3) a coefficient of thermal expansion similar to the tooth, which prevents stresses resulting from the mismatch and prevent micro-leakage of saliva and bacteria; 4) low shrinkage to prevent microleakage; 5) good mechanical properties, and 6) resistance to water adsorption. In addition, recent studies have also focused on producing composites that are more biologically active, produce less stresses during polymerisation, and have re-mineralisation properties. Thus, promoting more favourable host interactions and superior tooth integrity [25].

Resin-based composites are made from a variety of filler particle types. The mass ratio between filler particles and the organic matrix determines the composite's strength, its ability to handle masticatory stresses and its ability to withstand wear during mastication [200]. There are three filler particle type categories: 1) macro-fill particles; 2) micro-fill particles, and 3) hybrids, which are a combination of both macro-fill and micro-fill particles [201]. Early composites were reinforced with just macro-fill particles, while recent composites have also included micro-fill and hybrid composites. Macro-fill composites have the strength to resist masticatory stresses generated during the crushing and grinding of food and are commonly used in posterior restorations [202]. Unfortunately, macrofill composites are difficult to polish, which makes them unsuitable for anterior restorations. On the other hand, micro-fill composites, with smaller particle sizes are much easier to polish, and as a result are generally used for anterior restorations [203]. Importantly, composite properties can be modified to suit particular restorations by adjusting parameters such as filler particle size, type and quality of accelerators and coupling agents, and the type of polymerization activation process. Also, resins without filler particles have low viscosities, which enables them to be used to fill surface pits or be used to seal fissures [204]. However, in spite of their aesthetics and advantageous properties, micro-fill composites tend to be technique-sensitive, time-consuming and expensive [204, 205].

During the evolution of resin-based composites there has been a gradual decrease in filler particle size. In recent years, several nanomaterials have been incorporated into resin-based composites as a method of improving mechanical properties such as elastic modulus, flexural strength and wear resistance [206, 207]. Typical nanomaterials used as fillers include: alumina, hydroxyapatite, titania, silica and zirconia [208]. However, because of the large surface area and high surface charge of nanoparticles they need to be dispersed in a liquid phase before mixing with the resin matrix. However, the liquid phase usually contains a combination of dispersed nanoparticles (less than $100 \mathrm{~nm}$ ) and porous clusters of agglomerated nanoparticles. Nano-clusters form as a result of nanoparticles agglomerating in an effort to minimise their surface energy. Studies have revealed composites incorporating nanoparticles have improved strength and fracture resistance. The internal porous structure of nano-clusters allows the entry of coupling agents. The resulting penetration forms an interpenetrating structure that enhances the mechanical properties of the individual nano-clusters [209]. The nano-clusters behave like the larger particles found in micro-fillers. Thus, nano-filler-based composites tend to be stronger, have less shrinkage and can 
be polished $[11,210]$. However, studies have also revealed the presence of voids in nano-clusters that produce a greater tendency for cracking and subsequent failure under loading [209, 211]. Hence, further research into nano-filled composites is needed to improve and optimise material properties.

\subsubsection{Glass-Ionomer Cements}

Most commonly used alternative to resin-based composites are glass-ionomer cements (GICs) of which some are listed in Table 3. The material properties of GICs can be modified by varying the powder/liquid ratio or by changing their formulation, which enables them to be used in a variety of dental procedures [212]. Their use as a base material was reported to show lower stress concentration in dentine and improved biomechanical behaviour when simulated using 3D tooth models [213]. Studies during the 1960's found polyacrylic acid could complex with calcium, forming hydrogen bonds that made it possible for this cement to chemically adhere to mineralized dental tissues [52]. Later, high fluorine containing aluminosilicate glasses were found to react with polyacrylic acid via an acid-base reaction to form a paste. These pastes could then be used to fill a prepared tooth cavity to form a stable filling [214]. On setting, GICs were found to be more aesthetically attractive than traditional metallic amalgams [215]. In addition, fluorine rich GICs also release fluoride ions that give the filling anticariogenic properties which, also adhere to moist tooth structures and display favourable biocompatibility towards oral tissues [57]. However, low mechanical strength, low fracture toughness and brittleness limited their use to posterior dental regions [216, 217]. Studies found the lower mechanical properties were the result of moisture contamination occurring immediately after cement mixing [218]. While several studies have reported factors like: 1 ) particle size; 2 ) porosity distribution within the microstructure; 3) variations in the powder/liquid ratio, and 4) mixing method (air entrapment during mixing) can directly influence mechanical properties [216, 219]. For instance, mixing induced porosities of around 3 to $4 \%$ can produce a $50 \%$ reduction in strength [220]. Similarly, studies have also shown mixing procedures incorporating centrifugation or carried out under vacuum can significantly reduce porosity and increase strength by around 39\% [221-223].

Table 3 A selection of commercially available Glass ionomer cements.

\begin{tabular}{|c|c|c|c|c|c|}
\hline $\begin{array}{l}\text { Commercial } \\
\text { name }\end{array}$ & Manufacturer & & Variants & Type & Main Composition \\
\hline \multirow[t]{3}{*}{ Fuji ${ }^{\circledR}$} & \multirow[t]{3}{*}{$\begin{array}{l}\text { GC America } \\
\text { (USA) }\end{array}$} & & $\begin{array}{l}\text { GC Fuji Plus, } \\
\text { II LC, CEM 2, }\end{array}$ & $\begin{array}{l}\text { Resin } \\
\text { reinforced } \\
\text { glass } \\
\text { ionomer } \\
\text { cement }\end{array}$ & $\begin{array}{l}\text { 2-hydroxyethyl } \\
\text { methacrylate (HEMA), } \\
\text { urethane dimethacrylate } \\
\text { (UDMA), ethoxylated } \\
\text { bisphenol-A dimethacrylate }\end{array}$ \\
\hline & & & $\begin{array}{l}\text { GC Fuji I, } \\
\text { TRIAGE, II, IX }\end{array}$ & $\begin{array}{l}\text { Conventional } \\
\text { glass }\end{array}$ & $\begin{array}{l}\text { (Bis-EMA), butylated } \\
\text { hydroxytoluene }(\mathrm{BHT}), \text { poly }\end{array}$ \\
\hline & & & GP & $\begin{array}{l}\text { ionomer } \\
\text { cements }\end{array}$ & $\begin{array}{llr}\text { (acrylic } & \text { acid), } & \text { silicon } \\
\text { dioxide, } & & \text { polybasic } \\
\text { carboxylic } & \text { acid, } & \text { poly }(n-\end{array}$ \\
\hline
\end{tabular}




$\begin{array}{llll}\text { EQUIA }^{\circledR} & \text { Glass hybrid butyl methacrylate) \& } \\ \text { Forte Fil } & \text { restoratives } & \text { TRADE SECRET mixtures }\end{array}$

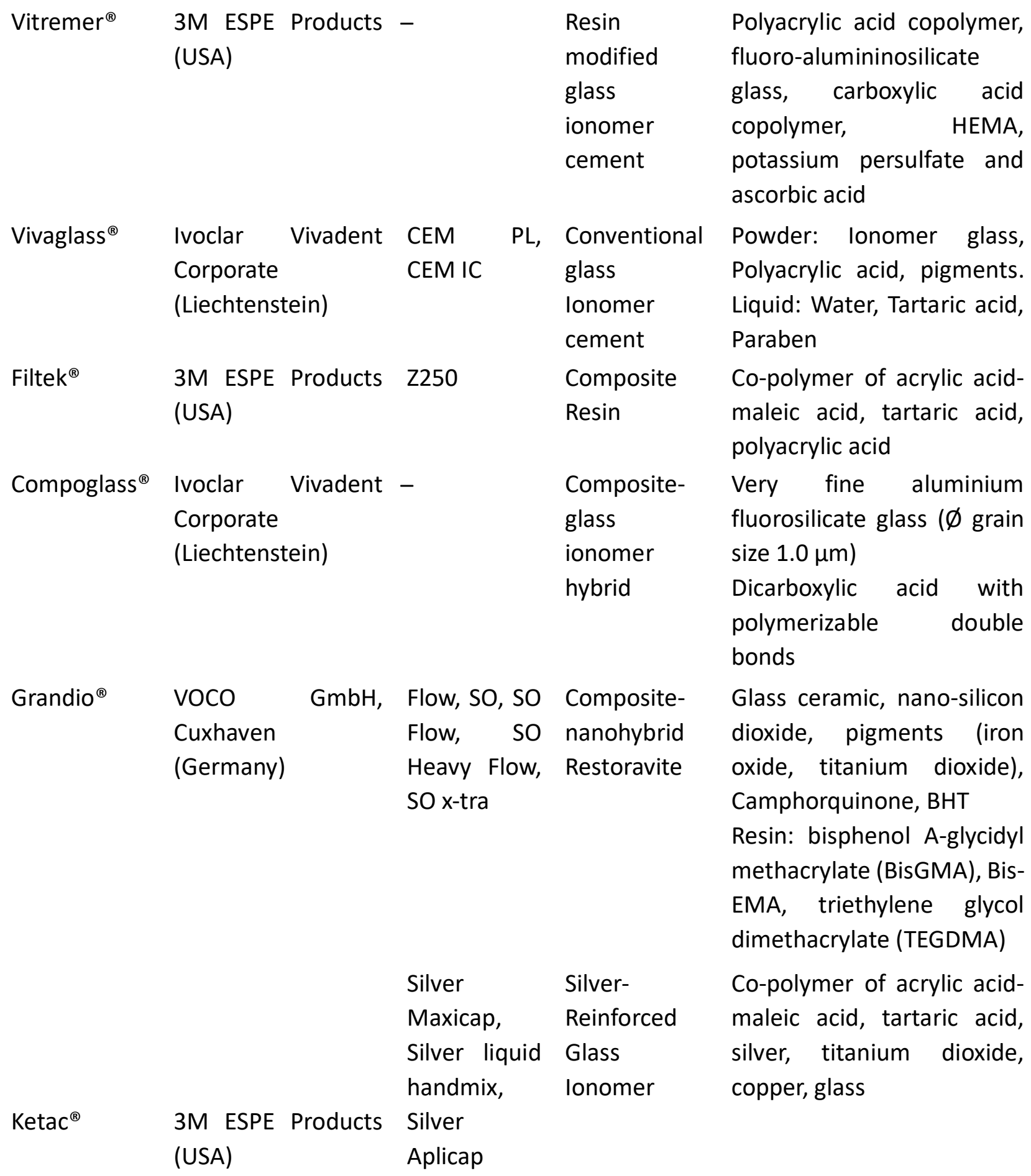




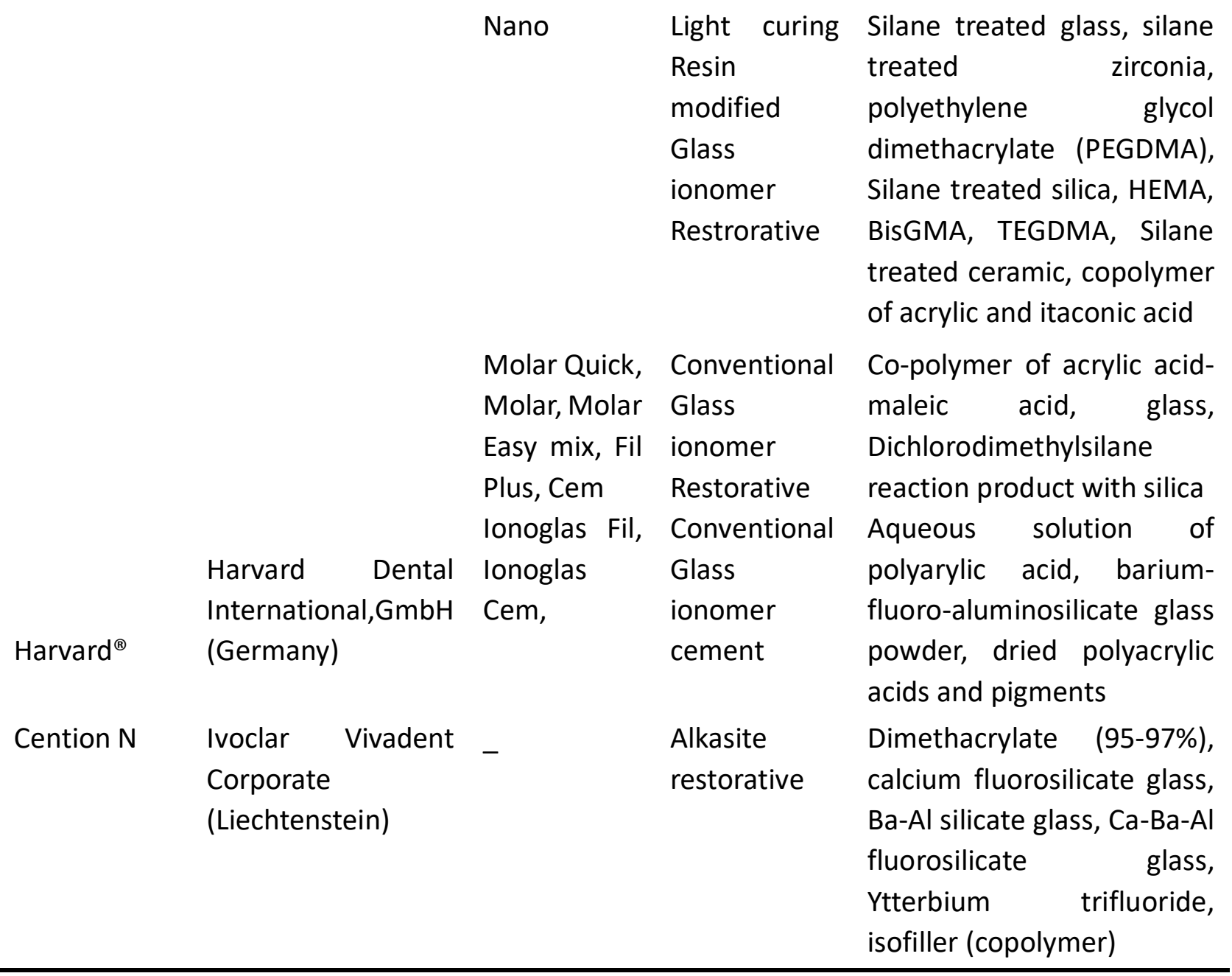

On the other hand, the coefficient of thermal expansion (CTE) between human enamel and GICs $(\sim 11.4 \mathrm{ppm})$ and porcelain ( $12 \mathrm{ppm})$ measured between 20 and $60^{\circ} \mathrm{C}$ are similar as seen in Table 1 [52]. This is of particular importance, since repeated expansions and contractions generated from the consumption of hot and cold foods and beverages can result in interface breaking between the filling and the tooth. Moreover, the thermal mismatch of materials such as amalgam and resin composites, will cause cycling thermal stresses at the tooth-filling interface. This continuous cycling overtime will ultimately break the seal and promote micro-leakage [224, 225].

Because of poor fracture toughness and low strength GICs, research has focused on incorporating various types of particles or fibres to as a method of improving mechanical properties. One of the earliest methods was to combine silver-based amalgams and GIC glass particles to form a new composite [226, 227]. In this composite a blended powder of components (1:1 ratio) is mixed with poly-carboxylic acid to produce a plastic paste. The paste hardens with time to form a ceramic/metallic composite cement commonly known as "Cermets" [221]. However, studies have revealed the bonding between ceramic and metallic components was less than satisfactory. In particular, when Cermets were used in posterior restorative procedures their durability was poor compared to conventional GIC restorations [228, 229]. While other studies have evaluated the use of materials such as alumina, carbon, calcium phosphates, glass, silicon carbide and zirconia to improve the mechanical performance of GICs. Studies have shown the inclusion of these types of fibres can significantly increase fracture toughness and strength [230]. For instance, the inclusion of 
glass fibres ( $40 \%$ wt.) can increase flexural strength by as much 4.5 times compared to unreinforced GICs [231]. The addition of glass fibres also increases fracture toughness by $140 \%$ when compared to unreinforced GICs [232]. While the inclusion of carbon fibres into the matrix can produce a fourfold increase in fracture strength $[233,234]$. Moreover, research has also focused on including slow release bioactive agents to promote bioactivity and biocompatibility $[235,236]$. Several GICs have been developed specifically to promote osteoconductivity, osteoinductivity and to promote the proliferation of various cells and tissues. For instance, bioactive GICs are used to replace hard tissues in oral, maxillofacial and orthopaedic surgical procedures [237, 238]. In particular, the inclusion of bioactive glass particles can significantly enhance bioactivity and physicochemical properties of GICs [239-241]. Several studies have also reported cellular properties such as gene activation, cell differentiation and cell proliferation are enhanced when exposed to bioactive glass [242, 243]. Unfortunately, studies have also reported that large concentrations of bioactive glass or similar bioactive materials in GICs compromises strength, toughness and hardness [244].

The reduction in mechanical performance resulting from increasing amounts of fillers has prompted research into incorporating nanometre scale materials known as nano-fillers [245]. Studies have found the addition of nano-fillers to CIGs produces highly desirable properties [30]. For instance, the presence of uniformly distributed nano-fillers in the CIGs matrix permit higher filler loads, decrease viscosity and reduce curing shrinkage [246]. The inclusion of nano-fillers has also been found to increase strength and hardness of these new composites by four to five times compared to conventional GICs [247]. For instance, the inclusion nano-zirconia oxide $\left(\mathrm{ZrO}_{2}\right)$ increases toughness by $20 \%$ [248] and the inclusion of carbon nanotubes (CNTs: $4 \%$ ) improves wear characteristics and mechanical properties by $30 \%[249,250]$. The most commonly used nanofillers include alumina, hydroxyapatite, silica, titania and zirconia [251-254].

\subsection{Calcium Phosphates and Hydroxyapatite}

The success of many dental materials depends on their interactions with surrounding oral tissues. Poor osseointegration or inflammatory responses from surrounding tissues resulting from infection leads to material rejection and restoration failure [255]. Importantly, during dental procedures one of the operative dental risk in light of the oral environment and microbiota is the possibility of microbes entering via a lesion. This creates competition between invading microbes and oral cells trying to colonise the surface of the dental material, a phenomenon known as "the race for the surface" [256]. If colonising oral cells are successful, infection is minimized, and the implant surface is covered with oral cells. However, if the number of invading microbes keep increasing, the resulting microbial population forms a biofilm that eventually prevents surrounding oral tissues interacting with the dental material. The lack of interaction results in poor integration and ultimately failure of the restoration [257]. Therefore, success of the dental procedure is determined by the behaviour of oral tissues and inflammatory responses resulting from infection [258]. Accordingly, surface chemistry and topography are important factors that must be considered when designing and manufacturing materials for dental procedures. Calcium phosphate (CaP) compounds are extensively used to coat metallic orthopaedic and dental implants to transform their surfaces to a more favourable biocompatible substrate. These coating are capable of promoting the formation of new bone or dental tissues [259, 260]. For instance, titanium (Ti) implants coated with CaP nanoparticles (20 to $100 \mathrm{~nm}$ ) display greater osseointegrative behaviour than uncoated implants 
[261, 262]. While in vitro studies have also shown osteoblasts have better proliferation rates on nano-CaP coated $\mathrm{Ti}$ implants compared to uncoated $\mathrm{Ti}$ implants [263]. The most commonly produced CaP materials include $\alpha$-tricalcium phosphate $(\alpha$-TCP), $\beta$-tricalcium phosphate $(\beta$-TCP), dicalcium phosphate, $\beta$-calcium pyrophosphate, hydroxyapatite (HAP), calcium deficient hydroxyapatite, octacalcium phosphate, oxyapatite, tetra calcium phosphate and biphasic HAP/ $\beta$ TCP mixtures (for further details refer to Table 4).

Table 4 A selection of different forms of calcium phosphate compounds currently used in commercial products (Dorozhkin [264]; Cimdina \& Borodajenko [265]; Prakasam M et al. [266]).

\begin{tabular}{|c|c|c|c|c|}
\hline Compound Name & $\begin{array}{l}\text { Crystal } \\
\text { Structure }\end{array}$ & $\begin{array}{l}\text { Chemical } \\
\text { Formula }\end{array}$ & $\begin{array}{l}\mathrm{Ca} / \mathrm{P} \\
\text { Ratio }\end{array}$ & $\begin{array}{l}\text { Commercial Product Name \& } \\
\text { Manufacturer }\end{array}$ \\
\hline $\begin{array}{l}\text { Monocalcium } \\
\text { phosphate } \\
\text { monohydrate }\end{array}$ & Triclinic & $\mathrm{Ca}\left(\mathrm{H}_{2} \mathrm{PO}_{4}\right)_{2} \cdot \mathrm{H}_{2} \mathrm{O}$ & 0.5 & $\begin{array}{lr}\text { Monocalcium Phosphate (DMH } \\
\text { Deutsche } & \text { Melasse } \\
\text { Handelsgesellschaft } & \mathrm{mbH}, \\
\text { Germany) } & \end{array}$ \\
\hline $\begin{array}{l}\text { Monocalcium } \\
\text { phosphate anhydrous }\end{array}$ & Triclinic & $\mathrm{Ca}\left(\mathrm{HPO}_{4}\right)_{2}$ & 0.5 & \\
\hline $\begin{array}{lr}\text { Dicalcium } & \text { phosphate } \\
\text { dihydrate } & \text { (mineral } \\
\text { brushite) } & \end{array}$ & Monoclinic & $\mathrm{CaHPO}_{4} \cdot 2 \mathrm{H}_{2} \mathrm{O}$ & 1.0 & Di-tab (Innophos, Inc., USA) \\
\hline $\begin{array}{l}\text { Di-calcium phosphate } \\
\text { anhydrous (mineral } \\
\text { monetite) }\end{array}$ & Triclinic & $\mathrm{CaHPO}_{4}$ & 1.0 & - \\
\hline $\begin{array}{l}\text { Amorphous calcium } \\
\text { phosphate }\end{array}$ & $\begin{array}{l}3 \text { polymorphs } \\
\text { Temp. based }\end{array}$ & $\begin{array}{l}\mathrm{Ca}_{x} \mathrm{H}_{y}\left(\mathrm{PO}_{4}\right)_{z} \cdot \mathrm{nH}_{2} \mathrm{O} \\
\mathrm{n}=3-4.5 \\
15-20 \% \mathrm{H}_{2} \mathrm{O}\end{array}$ & $\begin{array}{l}1.2 \\
\text { to } \\
2.2\end{array}$ & - \\
\hline $\begin{array}{l}\text { Octacalcium } \\
\text { phosphate } \\
\alpha \text {-tricalcium } \\
\text { phosphate }\end{array}$ & $\begin{array}{l}\text { Triclinic } \\
\text { Monoclinic }\end{array}$ & $\begin{array}{l}\mathrm{Ca}_{8}\left(\mathrm{HPO}_{4}\right)_{2}\left(\mathrm{PO}_{4}\right)_{4} \cdot \\
5 \mathrm{H}_{2} \mathrm{O} \\
\alpha-\mathrm{Ca}_{3}\left(\mathrm{PO}_{4}\right)_{2}\end{array}$ & $\begin{array}{l}1.33 \\
1.5\end{array}$ & - \\
\hline $\begin{array}{l}\beta \text {-tricalcium } \\
\text { phosphate }\end{array}$ & Rhombohedral & $\beta-\mathrm{Ca}_{3}\left(\mathrm{PO}_{4}\right)_{2}$ & 1.5 & $\begin{array}{l}\text { Bioresorb (Germany) } \\
\text { Calciresorb (Ceraver, France) } \\
\text { Cerasorb (Curasan, Germany) } \\
\text { JAX, Smith and Nephew (USA) } \\
\text { Graftys BCP (Graftys, France) } \\
\text { Osferion (Japan) }\end{array}$ \\
\hline $\begin{array}{l}\beta \text {-Calcium } \\
\text { pyrophosphate }\end{array}$ & - & $\mathrm{Ca}_{2} \mathrm{P}_{2} \mathrm{O}_{7}$ & $<1.5$ & - \\
\hline
\end{tabular}




\begin{tabular}{|c|c|c|c|c|}
\hline $\begin{array}{l}\text { Hydroxyapatite with } \\
\text { calcium deficient }\end{array}$ & - & $\begin{array}{l}\mathrm{Ca}_{10-} \\
x\left(\mathrm{HPO}_{4}\right)_{x}(\mathrm{PO})_{6-} \\
x(\mathrm{OH})_{2-x}(0<x<1)\end{array}$ & $\begin{array}{l}1.5- \\
1.67\end{array}$ & $\begin{array}{l}\text { Cementek (Teknimed, France) } \\
\text { Osteogen (Impladent, NY, USA) }\end{array}$ \\
\hline Hydroxyapatite & $\begin{array}{l}\text { Hexagonal } \\
\text { (Monoclinic at } \\
\text { temp. }<212^{\circ} \mathrm{C} \text { ) }\end{array}$ & $\mathrm{Ca}_{10}\left(\mathrm{PO}_{4}\right)_{6}(\mathrm{OH})_{2}$ & 1.67 & $\begin{array}{l}\text { Calcitite (Zimmer, IN, USA) } \\
\text { Bonefil (Mitsubishi, Japan) } \\
\text { Bonetite (Mitsubishi, Japan) } \\
\text { Cerapatite (Ceraver, France) } \\
\text { Synatite (SBM, France) } \\
\text { Apaceram (Pentax. Japan) }\end{array}$ \\
\hline Fluorapatite & - & $\mathrm{Ca}_{10}\left(\mathrm{PO}_{4}\right)_{6} \mathrm{~F}_{2}$ & 1.67 & $\begin{array}{l}\text { Phosphate Rock Fluorapatite } \\
\text { (Rotem Amfert Negev Ltd., } \\
\text { Israel) }\end{array}$ \\
\hline Oxyapatite & - & $\mathrm{Ca}_{10}\left(\mathrm{PO}_{4}\right)_{6} \mathrm{O}$ & 1.67 & - \\
\hline $\begin{array}{l}\text { Tetra } \\
\text { phosphate }\end{array}$ & Monoclinic & $\mathrm{Ca}_{4}\left(\mathrm{PO}_{4}\right) 2 \mathrm{O}$ & 2.0 & - \\
\hline
\end{tabular}

The most widely used member of the CaP family is hydroxyapatite (HAP). Its widespread use stems from its bioactive properties that facilitate new bone formation, promotes tissue integration and reducing healing time. Hence, its use to transform the smooth harsh surface of metallic implants to a more biocompatible and porous environment similar to hard tissues [267]. Implants made from metallic materials such as cobalt-chromium alloys, stainless steels and titanium alloys, which are coated with HAP display improved bone bonding, increased new bone formation and osteointegration [268]. There is also extensive ingrowth of connective tissues that stabilise the implant and reduces recovery time [269]. In addition, HAP is extensively used in orthopaedic procedures for example filling bone voids and bone coatings. For instance, Cerament ${ }^{\circledR}$ is a commercially available bone filler product that assists in the formation of new bone within 6 to 12 months after application [270]. Tooth enamel is the hardest and most highly mineralized structure found in humans. Although enamel is tough and abrasion-resistant, its high mineral content makes it brittle and prone to damage from mastication [271] while exposure to the acidic and bacterial rich oral environment overtime degrades the enamel surface.

Studies have shown that lost, damaged or eroded tooth enamel can be either replaced or remineralized using calcium phosphate-based materials [272]. In particular, HAP-based materials are widely used to resolve surface problems such as discolorations, voids and chips. In recent years nano-HAP has been used to repair enamel and used as a re-mineralizing agent in toothpastes [163, 167].

Interestingly, natural HAP found in bones and teeth is non-stoichiometric and displays variable deficiencies in $\mathrm{Ca}, \mathrm{P}$ and $\mathrm{OH}$. These deficiencies are made up by ionic substitutions of different types and amounts of elements such as magnesium, strontium, sodium, and silicon [273]. The presence of these substitutions changes the structure and surface chemistry of HAP, which in turn influences the biochemistry of bones, enamel and dentine [274]. The influence of these ionic species in hard tissues has not been fully elucidated. But studies by Carlisle revealed the presence and importance of small concentrations of silicon in osteoid regions of young mice and rats, which indicates the role of silicon in the early stages of bone formation and calcification $[275,276]$. Similar in vitro and in vivo studies have also shown the important role of silicon in the growth and development of hard 
tissues [277, 278]. Similar studies have found the inclusion of magnesium in HAP acts as a growth factor and stimulates osteoblast proliferation [279]. Currently, granular and powder forms of HAP are used in a variety of dental procedures that include: 1) restoration of periodontal bone defects [280]; 2) edentulous ridge augmentation [281]; 3) increasing the thickness of atrophic alveolar ridges; 4) filling bone defects after cystectomy; 5) endodontic treatment procedures such as repairing bifurcation perforations and pulp-capping [282, 283], and 6) dental implant coating [284]. While shaped HAP blocks are used in maxillofacial surgery to repair and reconstruct bone damage after trauma or disease. Furthermore, both micro-scale and nano-scale forms of HAP have been used as fillers for reinforcing GICs and restorative resin composites [285-287]. The potential hydroxyapatite-based nanomaterial composites can be mixed with the polymer resin as a restorative approach to replace the damaged tooth cavities (see Figure 5).

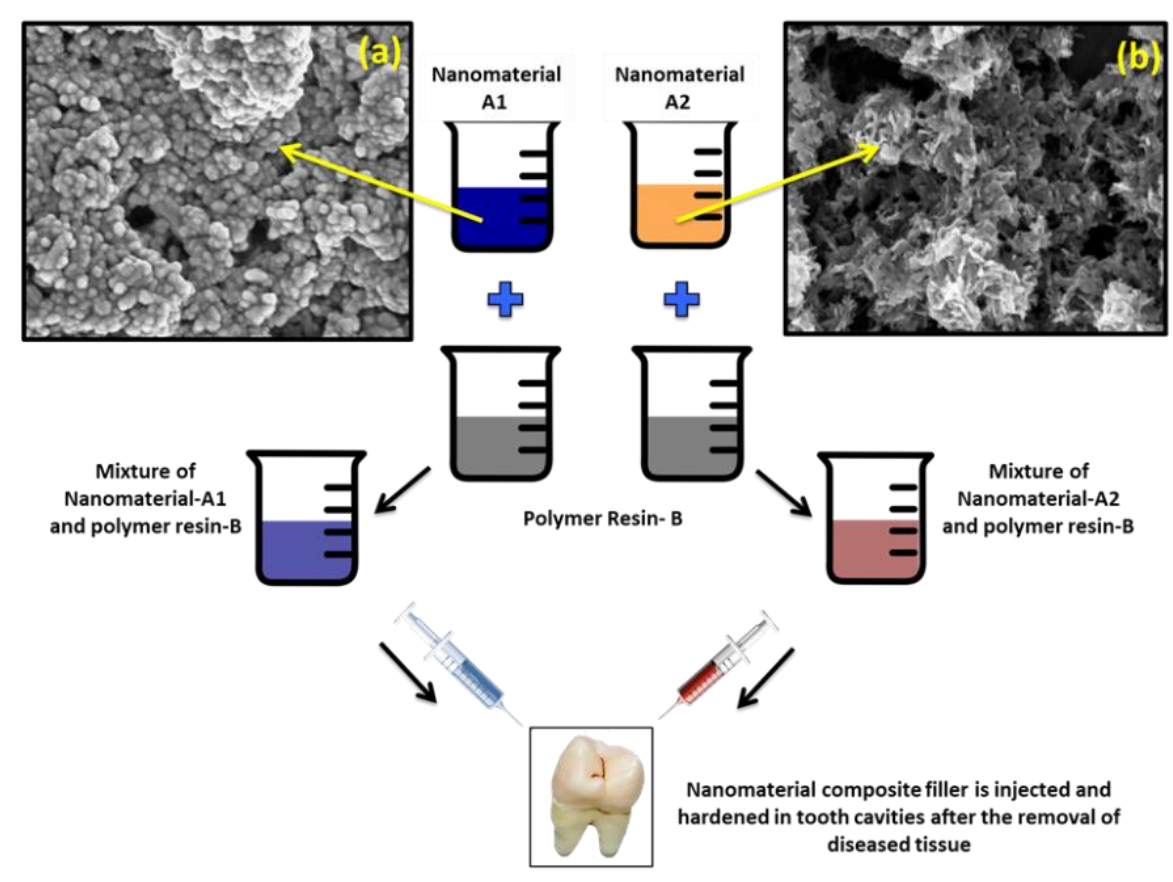

Figure $5 \mathrm{~A}$ schematic presentation of two potential restorative methods for producing dental fillings: (A1) sonochemically engineered hydroxyapatite nano-spheres [288]; (A2) sonochemically engineered hydroxyapatite nanorods; with respective scanning electron micrograph images of synthesised nanomaterial materials presented in (a) and (b)hydroxyapatite crystals.

\section{Health and Safety Risks of Nanomaterials in Dentistry}

Interactions between nanomaterials, living organisms and the environment are complex in nature and currently not fully understood. The main features of nanomaterials are their large surface area to volume ratios and greater surface reactivity. These features make their physicochemical properties significantly different from the same material at the macro-scale size [148]. Nanomaterials released into the environment can readily bind and interact with biological matter. This interaction changes their surface characteristics. Further surface changes can result from environmental factors such as $\mathrm{pH}$, the presence of other materials and temperature [289]. These interactions and property modifications can also adversely change the eco-system they are 
in [290]. The presence of nanomaterials in the environment can have a negative impact on human health. Since exposure and subsequent absorption through the skin, digestive tract and lungs permits their entry into the body [291]. The uptake of nanoparticles via respiratory tract after inhalation or through oral route has urged the need to study their physiological impact. Exposure and potential toxicity can also result from dental procedures such as: 1 ) ingestion of nanomaterials in dental products during or after treatment; 2 ) inhalation of aerosols generated from nanomaterialbased composites during drilling, and 3) the direct interaction between nanomaterials and cellular tissues in the oral cavity [292]. Importantly, nanomaterials can readily interact with cell constituents such as DNA molecules, proteins and intracellular components. These interaction mechanisms, elimination pathways and immune responses are difficult to predict and understand. This uncertainty arises from nanomaterials of the same material displaying different behavioural characteristics towards particular cellular tissues. For instance, size range, surface charge and surface chemistry resulting from coatings can change the behaviour of nanomaterials towards cellular tissues [293]. Materials used in dental procedures are intended to be passive towards oral tissues and chemically stable in the oral environment for long periods of time. Studies have reported the release of metal ions from amalgams and metal alloys [182]. Furthermore, other studies have reported the release of various chemical species from resin composites and dental sealers [294296]. To date, there are no studies evaluating the potential toxicity of dental products containing nanomaterials. Thus, there is a clear need for more research to develop new nanomaterial-based dental products, but also to identify and evaluate the potential hazards resulting from exposure to these new products both in the short and long-term [297]. Data from such studies would help to develop systemic solutions for delivery of safe and successful clinical outcomes for patients and dental professionals [298].

\section{Future Perspectives}

The demand for new dental products continues to be an active scientific and commercial endeavour. Currently there is no one product that meets all the necessary properties and requirements for preventative or restorative applications. However, advances in nanotechnologybased strategies for developing new products is believed to be the most effective method of delivering positive outcomes for patients. There are several active areas of research currently being investigated. For instance, to reduce anxiety and provide greater patient comfort during dental procedures, colloidal solutions composed of millions of active nanometre scale robots could be introduced into the oral cavity to shut down specific nerves. Once in the oral cavity, the practitioner directs the nano-robots to specific tooth locations or soft tissues. The nano-robots then migrate into tissue structures to specific targeted nerves and shut down their sensitivity. Then after the dental procedure, the practitioner commands the nano-robots to restore nerve sensitivity and leave the tissues [31, 299]. Similarly, orthodontic nano-robots could be used to remodel periodontal tissues and allow tooth straightening, rotation, and repositioning without pain in minutes to a few hours [300, 301]. Alternatively, nano-robotic dentifrices could be used to transport and distributed toothpastes or mouthwashes to breakdown organic matter or oral microbes into harmless byproducts [28]. Similarly, nano-robots could also be used to deliver pharmaceuticals and antibiotics (nano-encapsulation) [302, 303]. While nano-sensors/robots could be used to detect and identify 
harmful materials in order to assist in diagnosing and treating diseases, and ultimately improve the wellbeing of patients [149, 304].

Moreover, recent studies have witnessed the engineering of high strength nanomaterials into dental polymers to increase their strength and durability. For example, dental polymer fabricated with multi-layered graphene has shown a significant increase in the mechanical properties [305], stimulated tissue formation when graphene oxide implanted to collagen scaffold [306], and improved physicochemical and surface properties when dental polymer was reinforced with graphene gold nanoparticles [307]. Similarly, Carbon nanotubes (CNT's) and Boron Nitride nanoplatelets (BNNP's) have also captured attention and aroused the interest of many scientists as a potential biomaterial for dental applications [308-310]. A recent study highlighted the enhanced strength and fracture toughness of zirconia composite as a result of BNNPs reinforcement [310]. However, contradictory reports have shown the cytotoxic as well as non-cytotoxic properties of CNT's which opens up a debate on its potential use as a bioceramic material [311-313]. Therefore, bio-kinetics and organ toxicity plays an important role in measuring the quantitative risk involved in the use of these high strength nanomaterials.

In addition, there is current research into developing smart nanomaterials that assist in repair, promote cellular regeneration and osseointegration of bioactive dental implants [195, 314]. However, there are also challenges facing these new technologies. For instance, developing lowcost and mass produced nano-robotic platforms capable of undertaking their designed tasks. There is also a need to develop smart nanomaterials, protocols and nano-devices capable of delivering methods for disease monitoring, diagnosis, prevention and treatments tailored to individual patients.

\section{Conclusions}

This present review has highlighted the importance and use of emerging nanomaterials in preventative and restorative dentistry. Nano-dentistry has the potential to transform dentistry and deliver a wide range of novel products capable of delivering more effective health care strategies. However, as discussed above, the benefits need to be balanced against possible negative health effects resulting from exposure to these new and largely unknown products. Current studies suggest toxicity from the use of nanomaterials is low, but further research is needed to fully identify potential toxicity issues, arising from exposure levels and human-nanomaterial interaction mechanisms across the ages. Future longitudinal research may allay health-related concerns, while practitioner and public acceptance and adoption are needed before nano-dentistry can deliver a new era of health care benefits.

\section{Acknowledgments}

Mrs S Rattan would like to acknowledge Murdoch University for Murdoch International Postgraduate Scholarship for this work. The authors wished to thank Mr Wisut Chamsa-ard for his assistance with the graphical illustrations.

\section{Author Contributions}

All authors contributed to the writing of this review. 


\section{Competing Interests}

The authors have declared that no competing interests exist.

\section{References}

1. Ring ME. Dentistry: An illustrated history. 2nd ed. New York: Abradale Press; 1985.

2. Asbell MB. Dentistry: A historical perspective: Being a historical account of the history of dentistry from ancient times, with emphasis upon the United States from the colonial to the present period. Pittsburgh: Dorrance Publishing Company; 1988.

3. Gelbier S. 125 years of developments in dentistry, 1880--2005 part 2: Law and the dental profession. Br Dent J. 2005; 199: 470-473.

4. Abraham CM. A brief historical perspective on dental implants, their surface coatings and treatments. Open Dent J. 2014; 8: 50-55.

5. Linkow LI, Dorfman JD. Implantology in dentistry. A brief historical perspective. N Y State Dent J. 1991; 57: 31-35.

6. Branemark PI. Osseointegration and its experimental background. J prosthet Dent. 1983; 50: 399-410.

7. World Health Organization. Oral health. Fact sheet. Geneva: World Health Organization; 2012.

8. Public Health England. Child oral health: Applying all our health [Internet]. London: Public Health England; 2019. [cited date 2019 August 18th]. Available from: https://www.gov.uk/government/publications/child-oral-health-applying-all-our-health.

9. Australian Institute of Health and Welfare. Oral health and dental care in Australia 2015 [Internet]. Canberra: Australian Institute of Health and Welfare; 2016. [cited date 2019 August 18th]. Available from: https://www.aihw.gov.au/reports/dental-oral-health/oral-health-anddental-care-in-australia-2015/contents/oral-health-in-australia.

10. Fejerskov O, Kidd E. Dental caries: The disease and its clinical management. 2nd Ed. Oxford: Blackwell Munksgaard; 2008.

11. Mitra SB, Wu D, Holmes BN. An application of nanotechnology in advanced dental materials. J Am Dent Assoc. 2003; 134: 1382-1390.

12. Kern JK, Geier DA, Bjørklund G, King PG, Homme KG, Haley BE, et al. Evidence supporting a link between dental amalgams and chronic illness, fatigue, depression, anxiety, and suicide. Neuro Endocrinol Lett. 2014; 35: 535-552.

13. Rathore $M$, Singh A, Pant VA. The dental amalgam toxicity fear: A myth or actuality. Toxicol Int. 2012; 19: 81-88.

14. Abraham JE, Svare CW, Frank CW. The effect of dental amalgam restorations on blood mercury levels. J Dent Res. 1984; 63: 71-73.

15. Jones DW. A Canadian perspective on the dental amalgam issue. Br Dent J. 1998; 184: 581-586.

16. Bengtsson UG, Hylander LD. Increased mercury emissions from modern dental amalgams. Biometals. 2017; 30: 277-283.

17. Hyson Jr JM. Amalgam: Its history and perils. J Calif Dent Assoc. 2006; 34: 215-229.

18. Eley BM. The future of dental amalgam: A review of the literature. Part 7: Possible alternative materials to amalgam for the restoration of posterior teeth. Br Dent J. 1997; 183: 11-14. 
19. Imazato S. Antibacterial properties of resin composites and dentin bonding systems. Dent Mater. 2003; 19: 449-457.

20. Fan C, Chu L, Rawls HR, Norling BK, Cardenas HL, Whang K. Development of an antimicrobial resin-a pilot study. Dent Mater. 2011; 27: 322-328.

21. Xie D, Weng Y, Guo X, Zhao J, Gregory RL, Zheng C. Preparation and evaluation of a novel glassionomer cement with antibacterial functions. Dent Mater. 2011; 27: 487-496.

22. Park S, Wang DH, Zhang D, Romberg E, Arola D. Mechanical properties of human enamel as a function of age and location in the tooth. J Mater Sci Mater Med. 2008; 19: 2317-2324.

23. He LH, Swain MV. Influence of environment on the mechanical behaviour of mature human enamel. Biomaterials. 2007; 28: 4512-4520.

24. ADOHTA (Australian Dental and Oral Health Therapists' Association Inc.), Restorative Materials, 2014.

25. Fugolin AP, Pfeifer CS. New resins for dental composites. J Dent Res. 2017; 96: 1085-1091.

26. Ozak ST, Ozkan P. Nanotechnology and dentistry. Eur J Dent. 2013; 7: 145-151.

27. Raval C, Vyas K, Gandhi U, Patel B, Patel P. Nanotechnology in dentistry: A Review. J Adv Med Dent Sci Res. 2016; 4: 51-53.

28. Nagpal A, Kaur J, Sharma S, Bansal A, Sachdev P. Nanotechnology-the era of molecular dentistry. Indian J Dent Res. 2011; 3: 80-82.

29. Khurshid Z, Zafar M, Qasim S, Shahab S, Naseem M, AbuReqaiba A. Advances in nanotechnology for restorative dentistry. Materials. 2015; 8: 717-731.

30. Siang Soh M, Sellinger A, Uj Yap A. Dental nanocomposites. Curr Nanosci. 2006; 2: 373-381.

31. Mohan S, Gurtu A, Singhal A, Mehrotra A. Nanotechnology: Its implications in conservative dentistry and endodontics. J Oral Rehabil. 2013; 6: 9-13.

32. Chandra Mouli PE, Manoj Kumar S, Parthiban S. Nanotechnology in dentistry-a review. Int J Biol Med Res. 2012; 3: 1550-1553.

33. Kerebel B, Daculsi G, Kerebel LM. Ultrastructural studies of enamel crystallites. J Dent Res. 1979; 58: 844-851.

34. He LH, Swain MV. Nanoindentation derived stress-strain properties of dental materials. Dent Mater. 2007; 23: 814-821.

35. Husain MA. Dental anatomy and nomenclature for the radiologist. Radiol Clin. 2018; 56: 1-11.

36. Martín-de-Llano JJ, Mata M, Peydró S, Peydró A, Carda C. Dentin tubule orientation determines odontoblastic differentiation in vitro: A morphological study. PloS ONE. 2019; 14: e0215780.

37. Zheng $Q$, Xu H, Song F, Zhang L, Zhou X, Shao $Y$, et al. Spatial distribution of the human enamel fracture toughness with aging. J Mech Behav Biomed Mater. 2013; 26: 148-154.

38. Ryou H, Romberg E, Pashley DH, Tay FR, Arola D. Nanoscopic dynamic mechanical properties of intertubular and peritubular dentin. J Mech Behav Biomed Mater. 2012; 7: 3-16.

39. Braly A, Darnell LA, Mann AB, Teaford MF, Weihs TP. The effect of prism orientation on the indentation testing of human molar enamel. Arch Oral Biol. 2007; 52: 856-860.

40. Malek S, Darendeliler MA, Rex T, Kharbanda OP, Srivicharnkul P, Swain MV, et al. Physical properties of root cementum: Part 2. Effect of different storage methods. Am J Orthod Dentofacial Orthop. 2003; 124: 561-570.

41. Jeng YR, Lin TT, Hsu HM, Chang HJ, Shieh DB. Human enamel rod presents anisotropic nanotribological properties. J Mech Behav Biomed Mater. 2011; 4: 515-522. 
42. He LH, Yin ZH, van Vuuren LJ, Carter EA, Liang XW. A natural functionally graded biocomposite coating-human enamel. Acta Biomater. 2013; 9: 6330-6337.

43. Gutiérrez-Salazar MD, Reyes-Gasga J. Microhardness and chemical composition of human tooth. Mater Res. 2003; 6: 367-373.

44. He LH, Swain MV. Understanding the mechanical behaviour of human enamel from its structural and compositional characteristics. J Mech Behav Biomed Mater. 2008; 1: 18-29.

45. Ziskind D, Hasday M, Cohen SR, Wagner HD. Young's modulus of peritubular and intertubular human dentin by nano-indentation tests. J Struct Biol. 2011; 174: 23-30.

46. Guidoni G, Denkmayr J, Schöberl T, Jäger I. Nanoindentation in teeth: Influence of experimental conditions on local mechanical properties. Philos Mag. 2006; 86: 5705-5714.

47. Bertassoni LE, Swain MV. Influence of hydration on nanoindentation induced energy expenditure of dentin. J Biomech. 2012; 45: 1679-1683.

48. Lamont RJ, Koo H, Hajishengallis G. The oral microbiota: Dynamic communities and host interactions. Nat Rev Microbiol. 2018; 16: 745-759.

49. He LH, Fujisawa N, Swain MV. Elastic modulus and stress-strain response of human enamel by nano-indentation. Biomaterials. 2006; 27: 4388-4398.

50. Esser M. Material characteristics of the hard tissues of bovine versus human teeth. Dtsch Zahnarztl Z. 1998; 53: 713-717.

51. Angker L, Swain MV, Kilpatrick N. Characterising the micro-mechanical behaviour of the carious dentine of primary teeth using nano-indentation. J Biomech. 2005; 38: 1535-1542.

52. Craig RG. Restorative Dental Materials. 11th Ed. London: Mosby; 2002.

53. Al-Haik MS, Trinkle S, Garcia D, Yang F, Martinez U, Sumali H, et al. Investigation of the nanomechanical and tribological properties of dental materials. Int J Theor Appl Multiscale Mech. 2009; 1: 1-15.

54. Chorfa A, Madjoubi MA, Hamidouche M, Bouras N, Rubio J, Rubio F. Glass hardness and elastic modulus determination by nanoindentation using displacement and energy methods. Ceram Silik. 2010; 54: 225-234.

55. Xie D, Zhao J, Yang Y, Park J, Chu TM, Zhang JT. Preparation and evaluation of a high-strength biocompatible glass-ionomer cement for improved dental restoratives. Biomedical Mater. 2008; 3: 025012.

56. Drummond JL. Degradation, fatigue, and failure of resin dental composite materials. J Dent Res. 2008; 87: 710-719.

57. Lohbauer U. Dental glass ionomer cements as permanent filling materials?-Properties, limitations and future trends. Materials. 2010; 3: 76-96.

58. Rosa RS, Balbinot EA, Blando E, Mota EG, Oshima HM, Hirakata LM, et al. Evaluation of mechanical properties on three nanofilled composites. Stomatologija. 2012; 14: 126-130.

59. Turnbaugh PJ, Ley RE, Hamady M, Fraser-Liggett CM, Knight R, Gordon Jl. The human microbiome project. Nature. 2007; 449: 804-810.

60. Huttenhower C, Gevers D, Knight R, Abubucker S, Badger JH, Chinwalla AT, et al. Structure, function and diversity of the healthy human microbiome. Nature. 2012; 486: 207-214.

61. Palmer Jr RJ. Composition and development of oral bacterial communities. Periodontol. 2000. 2014; 64: 20-39. 
62. Marsh PD. Dental plaque: Biological significance of a biofilm and community life-style. J Clin Periodontol. 2005; 32: 7-15.

63. Wade WG. The oral microbiome in health and disease. Pharmacol Res. 2013; 69: 137-143.

64. He J, Li Y, Cao Y, Xue J, Zhou X. The oral microbiome diversity and its relation to human diseases. Folia Microbiol. 2015; 60: 69-80.

65. Warinner C, Rodrigues JF, Vyas R, Trachsel C, Shved N, Grossmann J, et al. Pathogens and host immunity in the ancient human oral cavity. Nat Genet. 2014; 46: 336-344.

66. Marsh PD. Contemporary perspective on plaque control. Br Dent J. 2012; 212: 601-606.

67. Gharechahi M, Moosavi H, Forghani M. Effect of surface roughness and materials composition. J Biomater Nanobiotechnol. 2012; 3: 541-546.

68. Aas JA, Paster BJ, Stokes LN, Olsen I, Dewhirst FE. Defining the normal bacterial flora of the oral cavity. J Clin Microbiol. 2005; 43: 5721-5732.

69. Marsh PD, Martin MV, Lewis MA, Williams D. Oral microbiology. 5th ed. Oxford: Churchill Livingstone; 2009.

70. Avila M, Ojcius DM, Yilmaz Ö. The oral microbiota: Living with a permanent guest. DNA Cell Biol. 2009; 28: 405-411.

71. Vollaard EJ, Clasener HA. Colonization resistance. Antimicrob Agents Chemother. 1994; 38: 409414.

72. Wescombe PA, Heng NC, Burton JP, Chilcott CN, Tagg JR. Streptococcal bacteriocins and the case for Streptococcus salivarius as model oral probiotics. Future Microbiol. 2009; 4: 819-835.

73. Burton JP, Chilcott CN, Moore CJ, Speiser G, Tagg JR. A preliminary study of the effect of probiotic Streptococcus salivarius K12 on oral malodour parameters. J Appl Microbiol. 2006; 100: 754-764.

74. Sullivan $\AA$, Edlund C, Nord CE. Effect of antimicrobial agents on the ecological balance of human microflora. Lancet Infect Dis. 2001; 1: 101-114.

75. Bik EM, Long CD, Armitage GC, Loomer P, Emerson J, Mongodin EF, et al. Bacterial diversity in the oral cavity of 10 healthy individuals. ISME J. 2010; 4: 962-974.

76. Segata N, Haake SK, Mannon P, Lemon KP, Waldron L, Gevers D, et al. Composition of the adult digestive tract bacterial microbiome based on seven mouth surfaces, tonsils, throat and stool samples. Genome Biol. 2012; 13: R42.

77. Crielaard W, Zaura E, Schuller AA, Huse SM, Montijn RC, Keijser BJ. Exploring the oral microbiota of children at various developmental stages of their dentition in the relation to their oral health. BMC Medical Genom. 2011; 4: 22.

78. Kazor CE, Mitchell PM, Lee AM, Stokes LN, Loesche WJ, Dewhirst FE, et al. Diversity of bacterial populations on the tongue dorsa of patients with halitosis and healthy patients. J Clin Microbiol. 2003; 41: 558-563.

79. Mager DL, Ximenez-Fyvie LA, Haffajee AD, Socransky SS. Distribution of selected bacterial species on intraoral surfaces. J Clin Periodontol. 2003; 30: 644-654.

80. Keijser BJ, Zaura E, Huse SM, Van der Vossen JM, Schuren FH, Montijn RC, et al. Pyrosequencing analysis of the oral microflora of healthy adults. J Dent Res. 2008; 87: 1016-1020.

81. Costalonga M, Herzberg MC. The oral microbiome and the immunobiology of periodontal disease and caries. Immunol Lett. 2014; 162: 22-38. 
82. Paster BJ, Boches SK, Galvin JL, Ericson RE, Lau CN, Levanos VA, et al. Bacterial diversity in human subgingival plaque. J Bacteriol. 2001; 183: 3770-3783.

83. Pedersen AM, Bardow A, Jensen SB, Nauntofte B. Saliva and gastrointestinal functions of taste, mastication, swallowing and digestion. Oral Dis. 2002; 8: 117-129.

84. Stookey GK. The effect of saliva on dental caries. J Am Dent Assoc. 2008; 139: 11S-17S.

85. Edgar WM, Higham SM, Manning RH. Saliva stimulation and caries prevention. Adv Dent Res. 1994; 8: 239-245.

86. Kumar PS, Griffen AL, Barton JA, Paster BJ, Moeschberger ML, Leys EJ. New bacterial species associated with chronic periodontitis. J Dent Res. 2003; 82: 338-344.

87. Mager DL, Haffajee AD, Devlin PM, Norris CM, Posner MR, Goodson JM. The salivary microbiota as a diagnostic indicator of oral cancer: A descriptive, non-randomized study of cancer-free and oral squamous cell carcinoma subjects. J Transl Med. 2005; 3: 27.

88. Mikkelsen H, Duck Z, Lilley KS, Welch M. Interrelationships between colonies, biofilms, and planktonic cells of Pseudomonas aeruginosa. J Bacteriol. 2007; 189: 2411-2416.

89. Renner LD, Weibel DB. Physicochemical regulation of biofilm formation. MRS Bull. 2011; 36 : 347-355.

90. Tuson HH, Weibel DB. Bacteria-surface interactions. Soft Matter. 2013; 9: 4368-4380.

91. Whitchurch CB, Tolker-Nielsen T, Ragas PC, Mattick JS. Extracellular DNA required for bacterial biofilm formation. Science. 2002; 295: 1487.

92. Bowen WH, Koo HJ. Biology of Streptococcus mutans-derived glucosyltransferases: Role in extracellular matrix formation of cariogenic biofilms. Caries Res. 2011; 45: 69-86.

93. Hannig C, Hannig M. The oral cavity-a key system to understand substratum-dependent bioadhesion on solid surfaces in man. Clin Oral Investig. 2009; 13: 123-139.

94. Marsh PD. Dental plaque as a biofilm and a microbial community-implications for health and disease. BMC Oral Health. 2006; 6: S14.

95. Takahashi N, Nyvad B. The role of bacteria in the caries process: Ecological perspectives. J Dent Res. 2011; 90: 294-303.

96. Gross EL, Leys EJ, Gasparovich SR, Firestone ND, Schwartzbaum JA, Janies DA, et al. Bacterial $16 \mathrm{~S}$ sequence analysis of severe caries in young permanent teeth. J Clin Microbiol. 2010; 48: 4121-4128.

97. Takahashi N, Nyvad B. Caries ecology revisited: Microbial dynamics and the caries process. Caries Res. 2008; 42: 409-418.

98. Filoche $\mathrm{S}$, Wong $\mathrm{L}$, Sissons $\mathrm{CH}$. Oral biofilms: Emerging concepts in microbial ecology. J Dent Res. 2010; 89: 8-18.

99. Burne RA, Marquis RE. Alkali production by oral bacteria and protection against dental caries. FEMS Microbiol Lett. 2000; 193: 1-6.

100. Burne RA, Zeng L, Ahn SJ, Palmer SR, Liu Y, Lefebure T, et al. Progress dissecting the oral microbiome in caries and health. Adv Dent Res. 2012; 24: 77-80.

101. Wade W. Unculturable bacteria in oral biofilms. In: Dental plaque revisited: Oral biofilms in health and disease. Hoboken: Wiley; 1999. pp. 313-322.

102. Marsh PD, Featherstone A, McKee AS, Hallsworth AS, Robinson C, Weatherell JA, et al. A microbiological study of early caries of approximal surfaces in schoolchildren. J Dent Res. 1989; 68: 1151-1154. 
103. Kolenbrander PE, Andersen RN, Blehert DS, Egland PG, Foster JS, Palmer RJ. Communication among oral bacteria. Microbiol Mol Biol Rev. 2002; 66: 486-505.

104. Imbronito AV, Okuda OS, Maria de Freitas N, Moreira Lotufo RF, Nunes FD. Detection of herpesviruses and periodontal pathogens in subgingival plaque of patients with chronic periodontitis, generalized aggressive periodontitis, or gingivitis. J Periodontol. 2008; 79: 23132321.

105. Devine DA. Antimicrobial peptides in defence of the oral and respiratory tracts. Mol Immunol. 2003; 40: 431-443.

106. Schlecht LM, Peters BM, Krom BP, Freiberg JA, Hänsch GM, Filler SG, et al. Systemic Staphylococcus aureus infection mediated by Candida albicans hyphal invasion of mucosal tissue. Microbiology. 2015; 161: 168-181.

107.Xu H, Sobue T, Thompson A, Xie Z, Poon K, Ricker A, et al. Streptococcal co-infection augments Candida pathogenicity by amplifying the mucosal inflammatory response. Cell Microbiol. 2014; 16: 214-231.

108. Freestone P. Communication between bacteria and their hosts. Scientifica. 2013; 2013: 361073.

109. Bamford CV, Nobbs AH, Barbour ME, Lamont RJ, Jenkinson HF. Functional regions of Candida albicans hyphal cell wall protein Als3 that determine interaction with the oral bacterium Streptococcus gordonii. Microbiology. 2015; 161: 18-29.

110. Hasegawa Y, Mans JJ, Mao S, Lopez MC, Baker HV, Handfield M, et al. Gingival epithelial cell transcriptional responses to commensal and opportunistic oral microbial species. Infect Immun. 2007; 75: 2540-2547.

111. Slots J. Herpesviral-bacterial synergy in the pathogenesis of human periodontitis. Curr Opin Infect Dis. 2007; 20: 278-283.

112. Selwitz RH, Ismail Al, Pitts NB. Dental caries. Lancet. 2007; 369: 51-59.

113. Bradshaw DJ, McKee AS, Marsh PD. Effects of carbohydrate pulses and pH on population shifts within oral microbial communities in vitro. J Dent Res. 1989; 68: 1298-1302.

114. Bradshaw DJ, Marsh PD. Analysis of $\mathrm{pH}$-driven disruption of oral microbial communities in vitro. Caries Res. 1998, 32: 456-462.

115. Len AC, Harty DW, Jacques NA. Stress-responsive proteins are up regulated in Streptococcus mutans during acid tolerance. Microbiology. 2004; 150: 1339-1351.

116. Welin J, Wilkins JC, Beighton D, Wrzesinski K, Fey SJ, Mose-Larsen P, et al. Effect of acid shock on protein expression by biofilm cells of Streptococcus mutans. FEMS Microbiol Lett. 2003; 227: 287-293.

117. McNeill K, Hamilton IR. Effect of acid stress on the physiology of biofilm cells of Streptococcus mutans. Microbiology. 2004; 150: 735-742.

118. Downes J, Mantzourani M, Beighton D, Hooper S, Wilson MJ, Nicholson A, et al. Scardovia wiggsiae sp. Nov., isolated from the human oral cavity and clinical material, and emended descriptions of the genus Scardovia and Scardovia inopinata. Int J Syst Evol Microbiol. 2011; 61: 25-29.

119. Tanner AC, Kent Jr RL, Holgerson PL, Hughes CV, Loo CY, Kanasi E, et al. Microbiota of severe early childhood caries before and after therapy. J Dent Res. 2011; 90: 1298-1305.

120. Munson MA, Pitt-Ford T, Chong B, Weightman A, Wade WG. Molecular and cultural analysis of the microflora associated with endodontic infections. J Dent Res. 2002; 81: 761-766. 
121. Coventry J, Griffiths G, Scully C, Tonetti M. ABC of oral health: Periodontal disease. BMJ. 2000; 321: 36-39.

122.Zijnge V, van Leeuwen MB, Degener JE, Abbas F, Thurnheer T, Gmür R, et al. Oral biofilm architecture on natural teeth. PLoS ONE. 2010; 5: e9321.

123. Igic M, Kesic L, Lekovic V, Apostolovic M, Mihailovic D, Kostadinovic L, et al. Chronic gingivitis: The prevalence of periodontopathogens and therapy efficiency. Eur J Clin Microbiol Infect Dis. 2012; 31: 1911-1915.

124. Huang S, Yang F, Zeng X, Chen J, Li R, Wen T, et al. Preliminary characterization of the oral microbiota of Chinese adults with and without gingivitis. BMC Oral Health. 2011; 11: 33.

125. Socransky SS. Microbiology of periodontal disease-present status and future considerations. J Periodontol. 1977; 48: 497-504.

126. Pihlstrom BL, Michalowicz BS, Johnson NW. Periodontal diseases. Lancet. 2005; 366: 1809-1820.

127. Kim YJ, Choi YS, Baek KJ, Yoon SH, Park HK, Choi Y. Mucosal and salivary microbiota associated with recurrent aphthous stomatitis. BMC Microbiol. 2016; 16: 57.

128. Hijazi K, Lowe T, Meharg C, Berry SH, Foley J, Hold GL. Mucosal microbiome in patients with recurrent aphthous stomatitis. J Dent Res. 2015; 94: 87s-94s.

129. Meurman JH, Uittamo J. Oral micro-organisms in the etiology of cancer. Acta Odontol Scand. 2008; 66: 321-326.

130. Vogelmann R, Amieva MR. The role of bacterial pathogens in cancer. Curr Opin Microbiol. 2007; 10: 76-81.

131. Nagy KN, Sonkodi I, Szöke I, Nagy E, Newman HN. The microflora associated with human oral carcinomas. Oral Oncol. 1998; 34: 304-308.

132. Markopoulos AK. Current aspects on oral squamous cell carcinoma. Open Dent J. 2012; 6: 126130.

133. Schmidt BL, Kuczynski J, Bhattacharya A, Huey B, Corby PM. Changes in abundance of oral Microbiota associated with oral cancer. PloS One. 2014; 9: e98741

134. Lee WH, Chen HM, Yang SF, Liang C, Peng CY, Lin FM, et al. Bacterial alterations in salivary microbiota and their association in oral cancer. Sci Rep. 2017; 7: 16540.

135. Lim Y, Totsika M, Morrison M, Punyadeera C. Oral Microbiome: A new biomarker reservoir for oral and oropharyngeal cancers. Theranostics. 2017; 7: 4313-4321.

136. Koren O, Spor A, Felin J, Fåk F, Stombaugh J, Tremaroli V, et al. Human oral, gut, and plaque microbiota in patients with atherosclerosis. Proc Natl Acad Sci U S A. 2011; 108: 4592-4598.

137. Ramirez JH, Parra B, Gutierrez S, Arce RM, Jaramillo A, Ariza Y, et al. Biomarkers of cardiovascular disease are increased in untreated chronic periodontitis: A case control study. Aust Dent J. 2014; 59: 29-36.

138. da Silva RM, Caugant DA, Josefsen R, Tronstad L, Olsen I. Characterization of Streptococcus constellatus strains recovered from a brain abscess and periodontal pockets in an immunocompromised patient. J Periodontol. 2004; 75: 1720-1723.

139. Schiff E, Pick N, Oliven A, Odeh M. Multiple liver abscesses after dental treatment. J Clin Gastroenterol. 2003; 36: 369-371.

140. Kuo LC, Poison AM, Kang T. Associations between periodontal diseases and systemic diseases: A review of the inter-relationships and interactions with diabetes, respiratory diseases, cardiovascular diseases and osteoporosis. Public Health. 2008; 122: 417-433. 
141. Preshaw PM, Alba AL, Herrera D, Jepsen S, Konstantinidis A, Makrilakis K, et al. Periodontitis and diabetes: A two-way relationship. Diabetologia. 2012; 55: 21-31.

142. Hintao J, Teanpaisan R, Chongsuvivatwong V, Ratarasan C, Dahlen G. The microbiological profiles of saliva, supragingival and subgingival plaque and dental caries in adults with and without type 2 diabetes mellitus. Oral Microbiol Immunol. 2007; 22: 175-181.

143. Teeuw WJ, Gerdes VE, Loos BG. Effect of periodontal treatment on glycemic control of diabetic patients-a systematic review and meta-analysis. Diabetes Care. 2010; 33: 421-427.

144. Farrell JJ, Zhang L, Zhou H, Chia D, Elashoff D, Akin D, et al. Variations of oral microbiota are associated with pancreatic diseases including pancreatic cancer. Gut. 2012; 61: 582-588.

145. Ahn J, Chen CY, Hayes RB. Oral microbiome and oral and gastrointestinal cancer risk. Cancer Causes Control. 2012; 23: 399-404.

146. Shiga K, Tateda M, Saijo S, Hori T, Sato I, Tateno H, et al. Presence of Streptococcus infection in extra-oropharyngeal head and neck squamous cell carcinoma and its implication in carcinogenesis. Oncol Rep. 2001; 8: 245-248.

147. Narikiyo $M$, Tanabe $C$, Yamada $Y$, Igaki H, Tachimori $Y$, Kato $H$, et al. Frequent and preferential infection of treponema denticola, Streptococcus mitis, and Streptococcus anginosus in esophageal cancers. Cancer Sci. 2004; 95: 569-574.

148. Kanaparthy R, Kanaparthy A. The changing face of dentistry: Nanotechnology. Int J Nanomedicine. 2011; 6: 2799-2804.

149. Gupta J. Nanotechnology applications in medicine and dentistry. J Investig Clin Dent. 2011; 2: 81-88.

150. Sahoo SK, Parveen S, Panda JJ. The present and future of nanotechnology in human health care. Nanomed Nanotechnol Biol Med. 2007; 3: 20-31.

151. Cox M, Chandler J, Boyle A, Kneller P, Haslam R. Eighteenth and nineteenth century dental restoration, treatment and consequences in a British nobleman. Br Dent J. 2000; 189: 593-596.

152. Seo S, Mahapatra C, Singh RK, Knowles JC, Kim H. Strategies for osteochondral repair: Focus on scaffolds. J. Tissue Eng 2014; 5: 1-14.

153. Touger-Decker R, van Loveren C. Sugars and dental caries. Am J Clin Nutr. 2003; 78: 881S-892S.

154. Hannig C, Berndt D, Hoth-Hannig W, Hannig M. The effect of acidic beverages on the ultrastructure of the acquired pellicle-an in situ study. Arch Oral Biol. 2009; 54: 518-526.

155. Hannig $M$, Joiner $A$. The structure, function and properties of the acquired pellicle. Monogr Oral Sci. 2006; 19: 29-64.

156.Cummins D. The efficacy of a new dentifrice containing $8.0 \%$ arginine, calcium carbonate, and $1450 \mathrm{ppm}$ fluoride in delivering instant and lasting relief of dentin hypersensitivity. $\mathrm{J}$ Clin Dent. 2009; 20: 109-114.

157.Sun L, Chow LC. Preparation and properties of nano-sized calcium fluoride for dental applications. Dent Mater. 2008; 24: 111-116.

158. Komárek A, Lesaffre E, Härkänen T, Declerck D, Virtanen JI. A Bayesian analysis of multivariate doubly-interval-censored dental data. Biostatistics. 2005; 6: 145-155.

159. Fawell J, Bailey K, Chilton J, Dahi E, Fewtrell L, Magara Y. Fluoride in Drinking-Water. 1st Ed. Cornwall: World Health Organization (WHO); 2006.

160. Ferrari M. Cancer nanotechnology: Opportunities and challenges. Nat Rev Cancer. 2005; 5: 161171.

161. Baker JR. Nanotechnology and medicine. J Oral Maxillofac Surg. 2007; 65: 27. 
162. Min JH, Kwon HK, Kim BL. The addition of nano-sized hydroxyapatite to a sports drink to inhibit dental erosion-in vitro study using bovine enamel. J Dent. 2011; 39: 629-635.

163. Tschoppe $P$, Zandim DL, Martus P, Kielbassa AM. Enamel and dentine remineralization by nanohydroxyapatite toothpastes. J Dent. 2011; 39: 430-437.

164. Gambhir RS, Sogi GM, Nirola A, Sekhon T, Kakar H, Brar R. Nanotechnology in dentistry: Current achievements and prospects. J Orofac Sci. 2013; 5: 9-14.

165. Melo MA, Guedes SF, Xu HH, Rodrigues LK. Nanotechnology-based restorative materials for dental caries management. Trends Biotechnol. 2013; 31: 459-467.

166. Lu KL, Zhang JX, Meng XC, Wei GZ, Zhou ML. Effects of nano-hydroxyapatite on the artificial caries. Mater Sci Technol. 2006; 14: 633-636.

167.Li L, Pan H, Tao J, Xu X, Mao C, Gu X, Tang R. Repair of enamel by using hydroxyapatite nanoparticles as the building blocks. J Mater Chem. 2008; 18: 4079-4084.

168. Pepla E, Besharat LK, Palaia G, Tenore G, Migliau G. Nano-hydroxyapatite and its applications in preventive, restorative and regenerative dentistry: A review of literature. Ann Stomatol (Roma). 2014; 5: 108-114.

169. Roveri N, Battistella E, Bianchi CL, Foltran I, Foresti E, lafisco M, et al. Surface enamel remineralization: Biomimetic apatite nanocrystals and fluoride ions different effects. Journal of Nanomaterials. 2009; 2009: 746383.

170. Freitas Jr RA. Nanotechnology, nanomedicine and nanosurgery. Int J Surg. 2005; 3: 243-246.

171. Najibfard K, Ramalingam K, Chedjieu I, Amaechi BT. Remineralization of early caries by a nano hydroxyapatite dentifrice. J Clin Dent. 2011; 22: 139-143.

172. Cross KJ, Huq NL, Reynolds EC. Casein phosphopeptides in oral health-chemistry and clinical applications. Curr Pharm Des. 2007; 13: 793-800.

173. Marchisio O, Esposito M, Genovesi A. Salivary pH level and bacterial plaque evaluation in orthodontic patients treated with Recaldent ${ }^{\circledR}$ products. Int J Dent Hyg. 2010; 8: 232-236.

174. Reynolds EC, Cai F, Cochrane NJ, Shen P, Walker GD, Morgan MV, et al. Fluoride and casein phosphopeptide-amorphous calcium phosphate. J Dent Res. 2008; 87: 344-348.

175.Zero DT. Recaldent ${ }^{\mathrm{TM}}$-evidence for clinical activity. Adv Dent Res. 2009; 21: 30-34.

176. Kowalczyk A, Botuliński B, Jaworska M, Kierklo A, Pawinska M, Dąbrowska E. Evaluation of the product based on RecaldentTM technology in the treatment of dentin hypersensitivity. Adv Med Sci. 2006; 51: 40-42.

177. Iijima Y, Cai F, Shen P, Walker G, Reynolds C, Reynolds EC. Acid resistance of enamel subsurface lesions remineralized by a sugar-free chewing gum containing casein phosphopeptideamorphous calcium phosphate. Caries Res. 2004; 38: 551-556.

178. Reynolds EC. Remineralization of enamel subsurface lesions by casein phosphopeptidestabilized calcium phosphate solutions. J Dent Res. 1997; 76: 1587-1595.

179. Reynolds EC, Cain CJ, Webber FL, Black CL, Riley PF, Johnson IH, et al Anticariogenicity of calcium phosphate complexes of tryptic casein phosphopeptides in the rat. J Dent Res. 1995; 74: 12721279.

180. Earl JS, Wood DJ, Milne SJ. Nanoparticles for dentine tubule infiltration: An in vitro study. J Nanosci Nanotechno. 2009; 9: 6668-6674.

181. Chiang YC, Chen HJ, Liu HC, Kang SH, Lee BS, Lin FH, et al. A novel mesoporous biomaterial for treating dentin hypersensitivity. J Dent Res. 2010; 89: 236-240. 
182. Burwell AK, Litkowski LJ, Greenspan DC. Calcium sodium phosphosilicate (NovaMin): Remineralization potential. Adv Dent Res. 2009; 21: 35-39.

183. Kodaka T, Kuroiwa M, Okumura J, Mori R, Hirasawa S, Kobori M. Effects of brushing with a dentifrice for sensitive teeth on tubule occlusion and abrasion of dentin. J Electron Microsc. 2001; 50: 57-64.

184. Tai BJ, Bian Z, Jiang H, Greenspan DC, Zhong J, Clark AE, et al. Anti-gingivitis effect of a dentifrice containing bioactive glass (NovaMin ${ }^{\circledR}$ ) particulate. J Clin Periodontol. 2006; 33: 86-91.

185. Vollenweider M, Brunner TJ, Knecht S, Grass RN, Zehnder M, Imfeld T, et al. Remineralization of human dentin using ultrafine bioactive glass particles. Acta Biomater. 2007; 3: 936-943.

186. Shibata Y, He LH, Kataoka Y, Miyazaki T, Swain MV. Micromechanical property recovery of human carious dentin achieved with colloidal nano-beta-tri-calcium phosphate. J Dent Res. 2008; 87: 233-237.

187. Kleinberg I. SensiStat. A new saliva-based composition for simple and effective treatment of dentinal sensitivity pain. Dent Today. 2002; 21: 42-47.

188. Bertassoni LE, Habelitz S, Kinney JH, Marshall SJ, Marshall GW. Biomechanical perspective on the remineralization of dentin. Caries Res. 2009; 43: 70-77.

189. Brune D. Metal Release from dental biomaterials. Biomaterials. 1986; 7: 163-175.

190. Bernardo M, Luis H, Martin MD, Leroux BG, Rue T, Leitao J, et al. Survival and reasons for failure of amalgam versus composite posterior restorations placed in a randomized clinical trial. J Am Dent Assoc. 2007; 138: 775-783.

191. Sarrett DC. Clinical challenges and the relevance of materials testing for posterior composite restorations. Dent Mater. 2005; 21: 9-20.

192. Wiegand A, Buchalla W, Attin T. Review on fluoride-releasing restorative materials fluoride release and uptake characteristics, antibacterial activity and influence on caries formation. Dent Mater. 2014; 23: 343-362.

193. Sadeghi M, Lynch CD. The effect of flowable materials on the microleakage of Class II composite restorations that extend apical to the cemento-enamel junction. Oper Dent. 2009; 34: 306-311.

194. Ferracane JL. Resin composite-state of the art. Dent Mater. 2011; 27: 29-38.

195. Cramer NB, Stansbury JW, Bowman CN. Recent advances and developments in composite dental restorative materials. J Dent Res. 2011; 90: 402-416.

196. Opdam NJ, Van De Sande FH, Bronkhorst E, Cenci MS, Bottenberg P, Pallesen U, et al. Longevity of posterior composite restorations: A systematic review and meta-analysis. J Dent Res. 2014; 93: 943-949.

197. Chen MH. Update on dental nanocomposites. J Dent Res. 2010; 89: 549-560.

198. Khurshid Z, Zafar M, Qasim S, Shahab S, Naseem M, AbuReqaiba A. Advances in nanotechnology for restorative dentistry. Materials. 2015; 8: 717-731.

199.Stansbury JW. Curing dental resins and composites by photo-polymerization. J Esthet Dent. 2000; 12: 300-308.

200. Fortin D, Vargas MA. The spectrum of composites: New techniques and materials. J Am Dent Assoc. 2000; 131(suppl): 26S-30S.

201. Roeters JJ, Shortall AC, Opdam NJ. Can a single resin composite serve all purposes? Br Dent J. 2005; 23: 73-79.

202. Li Y, Swartz ML, Phillips RW, Moore BK, Roberts TA. Materials science effect of filler content and size on properties of composites. J Dent Res. 1985; 64: 1396-1401. 
203. Fahl Jr N. The aesthetic composite anterior single crown restoration. Pract Periodontics Aesthet Dent. 1997; 9: 59-70.

204. Van Meerbeek B, De Munck J, Yoshida Y, Inoue S, Vargas M, Vijay P, et al. Buonocore memorial lecture. Adhesion to enamel and dentin: Current status and future challenges. Oper Dent. 2003; 28: 215-235.

205. Manhart J, Kunzelmann KH, Chen HY, Hickel R. Mechanical properties of new composite restorative materials. J Biomed Mater Res. 2000; 53: 353-361.

206.Zhang XY, Zhang XJ, Huang ZL, Zhu BS, Chen RR. Hybrid effects of zirconia nanoparticles with aluminum borate whiskers on mechanical properties of denture base resin PMMA. Dent Mater J. 2014; 33: 141-146.

207. Cheng L, Zhou X, Zhong H, Deng X, Cai Q, Yang X. NaF-loaded core-shell PAN-PMMA nanofibers as reinforcements for Bis-GMA/TEGDMA restorative resins. Mater Sci Eng C Mater Biol Appl. 2014; 34: 262-269.

208. Elkassas D, Arafa A. The innovative applications of therapeutic nanostructures in dentistry. Nanomedicine. 2017; 13: 1543-1562.

209. Curtis AR, Palin WM, Flemming GJ, Shortall AC, Marquis PM. The mechanical properties of nanofilled resin-based composites: Characterizing discrete filler particles and agglomerates using a micromanipulation technique. Dent Mater. 2009; 25: 180-187.

210. Beun S, Glorieux T, Devaux J, Vreven J, Leloup G. Characterization of nanofilled compared to universal and microfilled composites. Dent Mater. 2007; 23: 51-59.

211.Šupová M, Martynková GS, Barabaszová K. Effect of nanofillers dispersion in polymer matrices: A review. Sci Adv Mater. 2011; 3: 1-25.

212. Nicholson JW. Chemistry of glass-ionomer cements: A review. Biomaterials. 1998; 19: 485-494.

213. Ausiello P, Ciaramella S, De Benedictis A, Lanzotti A, Tribst JP, Watts DC. The use of different adhesive filling material and mass combinations to restore class II cavities under loading and shrinkage effects: A 3D-FEA. Comput Methods Biomech Biomed Engin. 2020; 1-11.

214. McLean J W, Wilson A D. The clinical development of the glass-ionomer cements: Formulations and properties. Aust Dent J. 1977; 22: 31-36.

215. Yip HK, Tay FR, Ngo H, Smales RJ, Pashley DH. Bonding of contemporary glass ionomer cements to dentin. Dent Mater. 2001; 17: 456-470.

216. Xie D, Brantley WA, Culbertson BM, Wang G. Mechanical properties and microstructures of glass-ionomer cements. Dent Mater. 2000; 16: 129-138.

217. Lohbauer U, Frankenberger R, Krämer N, Petschelt A. Time-dependent strength and fatigue resistance of dental direct restorative materials. J Mater Sci Mater Med. 2003; 14: 1047-1053.

218. Saito S, Tosaki S, Hirota K. Advances in glass ionomer cements. Berlin, Germany: Quintessence Publishing Co; 1999; pp. 15-50.

219. Guggenberger R, May R, Stefan KP. New trends in glass-ionomer chemistry. Biomaterials. 1998; 19: 479-483.

220. Nomoto R, Komoriyama M, McCabe JF, Hirano S. Effect of mixing method on the porosity of encapsulated glass ionomer cement. Dent Mater. 2004; 20: 972-978.

221. Lohbauer U, Pelka M, Frankenberger R, Kramer N. Influence of mixing procedures on wear resistance of glass ionomer cements. J Dent Res. 1999; 78: 988.

222. Ngo H, Peters MC, Mount GJ. Porosity reduction as a way to increase shearing strength of capsulated glass-ionomer cements. Trans Acad Dent Mater. 1996; 9: 258. 
223.Jorgensen KD, Iwaku M, Wakumoto S. Vacuum-mixing of silicate cement. Acta Odontol Scand. 1969; 27: 453-465.

224. Wahl MJ, Schmitt MM, Overton DA, Gordon MK. Prevalence of cusp fractures in teeth restored with amalgam and with resin-based composite. J Am Dent Assoc. 2004; 135: 1127-1132.

225. Lambrechts P, Goovaerts K, Bharadwaj D, De Munck J, Bergmans L, Peumans M, et al. Degradation of tooth structure and restorative materials: A review. Wear. 2006; 261: 980-986.

226. Tjan AHL, Morgan D L. Metal-reinforced glass ionomers: Their flexural and bond strengths to tooth substrates. J Prosthet Dent. 1988; 59: 137-141.

227. Chung KH. The properties of metal-reinforced glass ionomer materials. J Oral Rehabil. 1993; 22: 79-87.

228. Sarkar NK. Metal-matrix interface in reinforced glass-ionomers. Dent Mater. 1999; 15: 421-425.

229. Kilpatrick NM, Murray JJ, McCabe JF. The use of a reinforced glass-ionomer cement for the restoration of primary molars: A clinical trial. Br Dent J. 1995; 179: 175-179.

230. Kobayashi M, Kon M, Miyai K, Asaoka K. Strengthening of glass-ionomer cement by compounding short fibres with $\mathrm{CaO}-\mathrm{P}_{2} \mathrm{O}_{5}-\mathrm{SiO}_{2}-\mathrm{Al}_{2} \mathrm{O}_{3}$ glass. Biomaterials. 2000; 21: 2051-2058.

231. Kawano F, Kon M, Kobayashi M, Miyai K. Reinforcement effect of short glass fibers with $\mathrm{CaO}$ $\mathrm{P}_{2} \mathrm{O}_{5}-\mathrm{SiO}_{2}-\mathrm{Al}_{2} \mathrm{O}_{3}$ glass on strength of glass-ionomer cement. J Dent. 2001; 29: 377-380.

232. Lohbauer $U$, Frankenberger $R$, Clare A, Petschelt A, Greil P. Toughening of glass ionomer cements by reactive glass fibers. Biomaterials. 2004; 25: 5217-5225.

233.Xu HH, Eichmiller FC, Barndt PR. Effects of fiber length and volume fraction on the reinforcement of calcium phosphate cement. J Mater Sci Mater Med. 2001; 12: 57-65.

234. Lohbauer U, Frankenberger R, Kramer N, Petschelt A. Strength and fatigue performance versus filler fraction of different types of direct dental restoratives. J Biomed Mater Res B Appl Biomater. 2006; 76:114-120.

235. Moshaverinia A, Ansari S, Movasaghi Z, Billington RW, Darr JA, Rehman IU. Modification of conventional glass-ionomer cements with $\mathrm{N}$-vinyl pyrrolidone containing polyacids, nanohydroxy and fluoroapatite to improve mechanical properties. Dental Mater. 2008; 24: 13811390.

236. De Paula AB, Fucio SB, Ambrosano GM, Alonso RC, Sardi JC, Puppin-Rontani RM. Biodegradation and abrasive wear of nano restorative materials. Oper Dent. 2011; 36: 670-677.

237. Hench LL. Bioceramics. J Am Ceram Soc. 2005; 81: 1705-1728.

238. Webster TJ. Improved bone tissue engineering materials. Am Ceram Soc Bull. 2003; 82: 23-28.

239. De Caluwé T, Vercruysse CW, Ladik I, Convents R, Declercq H, Martens LC, et al. Addition of bioactive glass to glass ionomer cements: Effect on the physico-chemical properties and biocompatibility. Dent Mater. 2017; 33: e186-e203.

240. Chen S, Cai Y, Engqvist H, Xia W. Enhanced bioactivity of glass ionomer cement by incorporating calcium silicates. Biomatter. 2016; 6: e1123842.

241. Khoroushi M, Mousavinasab SM, Keshani F, Hashemi S. Effect of resin-modified glass ionomer containing bioactive glass on the flexural strength and morphology of demineralized dentin. Oper Dent. 2013; 38: E21-E30.

242.Xie D, Zhao J, Weng Y, Park JG, Jiang H, Platt JA. Bioactive glass-ionomer cement with potential therapeutic function to dentin capping mineralization. Eur J Oral Sci. 2008; 116: 479-487.

243. Hench LL. The story of Bioglass. J Mater Sci Mater Med. 2006; 17: 967-978. 
244. Yli-Urpo H, Lassila LV, Närhi T, Vallittu PK. Compressive strength and surface characterization of glass ionomer cements modified by particles of bioactive glass. Dent Mater. 2005; 21: 201-209.

245. Persson C, Unosson E, Ajaxon I, Engstrand J, Engqvist H, Xia W. Nano grain sized zirconia-silica glass ceramics for dental applications. J Eur Ceram Soc. 2012; 32: 4105-4110.

246. Terry DA. Applications of Nanotechnology. Pract Proced Aesthet Dent. 2004; 16: 220-222.

247. Raj V, Mumjitha MS. Formation and surface characterization of nanostructured $\mathrm{Al}_{2} \mathrm{O}_{3}-\mathrm{TiO}_{2}$ coatings. Bull Mater Sci. 2014; 37: 411-1418.

248. Wang GK, Kang H, Bao GJ, Lv JJ, Gao F. Influence on mechanical properties and microstructure of nano-zirconia toughened alumina ceramics with nano-zirconia content. West Chin J Stomatol. 2006; 24: 404-406.

249. An JW, You DH, Lim DS. Tribological properties of hot-pressed alumina-CNT composites. Wear. 2003; 255: 677-681.

250. Peigney A, Laurent C, Flahaut E, Rousset A. Carbon nanotubes in novel ceramic matrix nanocomposites. Ceram Int. 2000; 26: 677-683.

251.Yu W, Wang X, Tang Q, Guo M, Zhao J. Reinforcement of denture base PMMA with $\mathrm{ZrO}_{2}$ nanotubes. J Mech Behav Biomed Mater. 2014; 32: 192-197.

252. Safi IN. Evaluation the effect of nano-fillers $\left(\mathrm{TiO}_{2}, \mathrm{Al}_{2} \mathrm{O}_{3}, \mathrm{SiO}_{2}\right)$ addition on glass transition temperature, e-moudulus and coefficient of thermal expansion of acrylic denture base material. J Baghdad Coll Dent. 2014; 26: 37-41.

253.Sadat-Shojai M, Atai M, Nodehi A, Khanlar LN. Hydroxyapatite nanorods as novel fillers for improving the properties of dental adhesives: Synthesis and application. Dent Mater. 2010; 26: 471-482.

254. Besinis A, van Noort R, Martin N. Infiltration of demineralized dentin with silica and hydroxyapatite nanoparticles. Dent Mater. 2012; 28: 1012-1023.

255. Moy P, Medina D, Shetty V, Aghaloo TL. Dental implant failure rates and associated risk factors. Int J Oral Max Impl. 2005; 20: 569-577.

256.Gristina AG. Biomaterial-centered infection: Microbial adhesion versus tissue integration. Science. 1987; 237: 1588-1595.

257. Odekerken JC, Welting TJ, Arts JJ, Walenkamp GH, Emans PJ. Modern orthopaedic implant coatings-their pro's, con's and evaluation methods. In: Modern surface engineering treatments. New York: InTech; 2013. pp. 45-73.

258. Xu Z, Sun J. Application of nanotechnology and nanomaterials in oral medicine. Dent Mater J. 2009; 18: 186-191.

259. Hamlet S, Ivanovski S. Inflammatory cytokine response to titanium chemical composition and nanoscale calcium phosphate surface modification. Acta Biomater. 2011; 7: 2345-2353.

260. Quaranta A, lezzi G, Scarano A, Coelho PG, Vozza I, Marincola M, et al. A histomorphometric study of nanothickness and plasma-sprayed calcium-phosphorous-coated implant surfaces in rabbit bone. J Periodontol. 2010; 81: 556-561.

261. Bucci-Sabattini V, Cassinelli C, Coelho PG, Minnici A, Trani A, Ehrenfest DM. Effect of titanium implant surface nanoroughness and calcium phosphate low impregnation on bone cell activity in vitro. Oral Surg Oral Med Oral Pathol Oral Radiol. 2010; 109: 217-224.

262. Telleman G, Albrektsson T, Hoffman M, Johansson CB, Vissink A, Meijer HJ, et al. Peri-implant endosseous healing properties of dual acid-etched mini-implants with a nanometer-sized 
deposition of CaP: A histological and histomorphometric human study. Clin Implant Dent Relat Res. 2010; 12: 153-160.

263. Webster TJ, Ergun C, Doremus RH, Siegel RW, Bizios R. Enhanced functions of osteoblasts on nanophase ceramics. Biomaterials. 2000; 21: 1803-1810.

264. Dorozhkin SV. Amorphous calcium (ortho) phosphates. Acta Biomaterialia. 2010; 6: 4457-4475.

265. Berzina-Cimdina L, Borodajenko N. Research of calcium phosphates using Fourier transform infrared spectroscopy. Infrared spectroscopy-materials science, engineering and technology. In: Infrared Spectroscopy: Materials Science, Engineering and Technology. Rijeka: InTech; 2012.

266. Prakasam M, Locs J, Salma-Ancane K, Loca D, Largeteau A, Berzina-Cimdina L. Fabrication, properties and applications of dense hydroxyapatite: A review. J Funct Biomater. 2015; 6: 10991140.

267. Yang GL, He FM, Hu JA, Wang XX, Zhao SF. Effects of biomimetically and electrochemically deposited nano-hydroxyapatite coatings on osseointegration of porous titanium implants. Oral Surg Oral Med Oral Pathol Oral Radiol. 2009; 107: 782-789.

268.Svanborg LM, Hoffman M, Andersson M, Currie F, Kjellin P, Wennerberg A. The effect of hydroxyapatite nanocrystals on early bone formation surrounding dental implants. Int J Oral Max Surg. 2011; 40: 308-315.

269. Goodman SB, Yao ZY, Keeney M, Yang F. The future of biologic coatings for orthopaedic implants. Biomaterials. 2013; 34: 3174-3183.

270. Lindberg F. Cerament ${ }^{\mathrm{TM}}$ | Bone Void Filler. Technical Monograph. 2013.

271. Nanci A. Ten Cate's Oral Histology: Development, Structure, and Function. 8th Ed. Maryland Heights: Mosby; 2012.

272. Cai Y, Tang R. Calcium phosphate nanoparticles in biomineralization and biomaterials. J Mater Chem. 2008; 18: 3775-3787.

273. Blumenthal NC, Betts F, Posner AS. Effect of carbonate and biological macromolecules on formation and properties of hydroxyapatite. Calcif Tissue Res. 1975; 18: 81-90.

274. LeGeros RZ. Calcium phosphates in oral biology and medicine. Monogr Oral Sci. 1991; 15: 109111.

275. Carlisle EM. Silicon: A possible factor in bone calcification. Science. 1970; 167: 279-280.

276. Carlisle EM. Silicon: A requirement in bone-formation independent of vitamin-D1. Calcif Tissue Int. 1981; 33: 27-34.

277. Hing KA, Revell PA, Smith N, Buckland T. Effect of silicon level on rate, quality and progression of bone healing within silicate-substituted porous hydroxyapatite scaffolds. Biomaterials. 2006; 27: 5014-5026

278. Patel N, Best SM, Bonfield W, Gibson IR, Hing KA, Damien E, et al. A comparative study on the in vivo behavior of hydroxyapatite and silicon substituted hydroxyapatite granules. J Mater Sci Mater Med. 2002; 13: 1199-1206

279. Landi E, Logroscino G, Proietti L, Tampieri A, Sandri M, Sprio S. Biomimetic Mg-substituted hydroxyapatite: From synthesis to in vivo behaviour. J Mater Sci Mater Med. 2008; 19: 239-247.

280. Meffert RM, Thomas JR, Hamilton KM, Brownstein CN. Hydroxylapatite as an alloplastic graft in the treatment of human periodontal osseous defects. J Periodontol. 1985; 56: 63-73.

281. Piecuch JF. Augmentation of the atrophic edentulous ridge with porous replamineform hydroxyapatite (Interpore-200). Dent Clin North Am. 1986; 30: 291-305. 
282.Jean A, Kerebel B, Kerebel LM, Legeros RZ, Hamel H. Effects of various calcium phosphate biomaterials on reparative dentin bridge formation. J Endod. 1988; 14: 83-87.

283. Pissiotis E, Spangberg LS. Biological evaluation of collagen gels containing calcium hydroxide and hydroxyapatite. J Endod. 1990; 16: 468-473.

284. Rigo EC, Boschi AO, Yoshimoto M, Allegrini Jr S, Kong Jr B, Corbani MJ. Evaluation in vitro and in vivo of biomimetic hydroxyapatite coated on titanium dental implants. Mater Sci Eng C. 2004; 24: $647-651$

285.Zhang H, Darvell BW. Mechanical properties of hydroxyapatite whisker-reinforced bis-GMAbased resin composites. Dent Mater. 2012; 28: 824-830.

286. Lee JJ, Lee YK, Choi BJ, Lee JH, Choi HJ, Son HK, et al. Physical properties of resin-reinforced glass ionomer cement modified with micro and nano-hydroxyapatite. J Nanosci Nanotechnol. 2010; 10: 5270-5276.

287. Arita K, Yamamoto A, Shinonaga Y, Harada K, Abe Y, Nakagawa K, et al. Hydroxyapatite particle characteristics influence the enhancement of the mechanical and chemical properties of conventional restorative glass ionomer cement. Dent Mater J. 2011; 30: 672-683.

288. Poinern GE, Brundavanam RK, Mondinos N, Jiang ZT. Synthesis and characterisation of nanohydroxyapatite using an ultrasound assisted method. Ultrason Sonochem. 2009; 16: 469474.

289. Rocks SA, Pollard SJ, Dorey RA, Harrison PT, Levy LS, Handy RD, et al. Risk assessment of manufactured nanomaterials. In: Environmental and Human Health Impacts of Nanotechnology. Hoboken: Blackwell Publishing Ltd; 2009. pp. 389-421.

290. Barnard AS. Nanohazards: Knowledge is our first defence. Nature Mater. 2006; 5: 245-248.

291. Schulte PA, Geraci CL, Murashov V, Kuempel ED, Zumwalde RD, Castranova V, et al. Occupational safety and health criteria for responsible development of nanotechnology. J Nanopart Res. 2014; 16: 2153.

292. Juillerat-Jeanneret L, Dusinska M, Fjellsb $\varnothing$ LM, Collins AR, Handy RD, Riediker M, et al. Biological impact assessment of nanomaterial used in nanomedicine. Introduction to the NanoTEST project. Nanotoxicology. 2015; 9: 5-12.

293. Bouwmeester H, Dekkers S, Noordam MY, Hagens WI, Bulder AS, de Heer C, et al. Review of health safety aspects of nanotechnologies in food production. Regul Toxicol Pharm. 2009; 53: 52-62.

294. Olea N, Pulgar R, Pérez P, Olea-Serrano F, Rivas A, Novillo-Fertrell A, et al. Estrogenicity of resinbased composites and sealants used in dentistry. Environ Health Persp. 1996; 104: 298-305.

295. Gerzina TM, Hume WR. Effect of dentine on release of TEGDMA from resin composite in vitro. J Oral Rehabil. 1994; 21: 463-468.

296. Ferracane JL. Elution of leachable components from composites. J Oral Rehabil. 1994; 21: 441452.

297. Engeman CD, Baumgartner L, Carr BM, Fish AM, Meyerhofer JD, Satterfield TA, et al. Governance implications of nanomaterials companies' inconsistent risk perceptions and safety practices. J Nanopart Res. 2012; 14: 749-761.

298. Hunt G, Lynch I, Cassee F, Handy RD, Fernandes TF, Berges M, et al. Towards a consensus view on understanding nanomaterials hazards and managing exposure: Knowledge gaps and recommendations. Materials. 2013; 6: 1090-1117. 
299. Markan S, Lehl G, Kapoor S. Recent advances of nanotechnology in endodontics, conservative and preventive dentistry-a review. J Dent Oral Biol. 2017; 2: 1067.

300. Patil M, Mehta DS, Guvva S. Future impact of nanotechnology on medicine and dentistry. J Indian Soc Periodontol. 2008; 12: 34-40.

301. Mikkilineni M, Rao AS, Tummala M, Elkanti S. Nanodentistry: New buzz in dentistry. Eur J Gen Dent. 2013; 2: 109-113.

302. Bhardwaj A, Bhardwaj A, Misuriya A, Maroli S, Manjula S, Singh AK. Nanotechnology in dentistry: Present and future. J Int Oral Health. 2013; 6: 121-126.

303. Verma SK, Prabhat KC, Goyal L, Rani M, Jain A. A critical review of the implication of nanotechnology in modern dental practice. Natl J Maxillofac Surg. 2010; 1: 41-44.

304. Fioretti F, Mendoza-Palomares C, Helms M, Al Alam D, Richert L, Arntz Y, et al. Nanostructured assemblies for dental application. ACS Nano. 2010; 4: 3277-3287.

305. Malik S, Ruddock FM, Dowling AH, Byrne K, Schmitt W, Khalakhan I, et al. Graphene composites with dental and biomedical applicability. Beilstein J Nanotechnol. 2018; 9: 801-808.

306. Kawamoto K, Miyaji H, Nishida E et al. Characterization and evaluation of graphene oxide scaffold for periodontal wound healing of class II furcation defects in dog. Int J nanomedicine. 2018; 13, 2365.

307. Sarosi C, Biris AR, Antoniac A, Boboia S, Alb C, Antoniac I, et al. The nanofiller effect on properties of experimental graphene dental nanocomposite. J Adhes Sci Technol. 2016; 30: 1779-1794.

308. Borges ALS, Tribst JPM, Piva AD, Souza AO. In vitro evaluation of multi-walled carbon nanotube reinforced nanofibers composites for dental application. Int J Polym Mater. 2020; 69: 10151022.

309. Kou W, Akasaka T, Watari F, Sjögren G. An in vitro evaluation of the biological effects of carbon nanotube-coated dental zirconia. Int Sch Res Notices. 2013; 2013: 296727.

310. Lee B, Kwon J, Khalid MW, Kim K, Kim J, Lim KM, Hong H. Boron nitride nanoplatelets as reinforcement material for dental ceramics. Dent Mater. 2020; 36: 744-754.

311. Cherukuri P, Bachilo SM, Litovsky SH, Weisman RB. Near-infrared fluorescence microscopy of single-walled carbon nanotubes in phagocytic cells. J Am Chem Soc. 2004; 126: 15638-15639.

312. Cheng C, Müller KH, Koziol KK, Skepper JN, Midgley PA, Welland ME, et al. Toxicity and imaging of multi-walled carbon nanotubes in human macrophage cells. Biomaterials. 2009; 30: 41524160.

313. Oberdörster G. Safety assessment for nanotechnology and nanomedicine: Concepts of nanotoxicology. J Intern Med. 2010; 267: 89-105.

314. McCabe JF, Yan Z, Al Naimi OT, Mahmoud G, Rolland SL. Smart materials in dentistry-future prospects. Dent Mater J. 2009; 28: 37-43. 


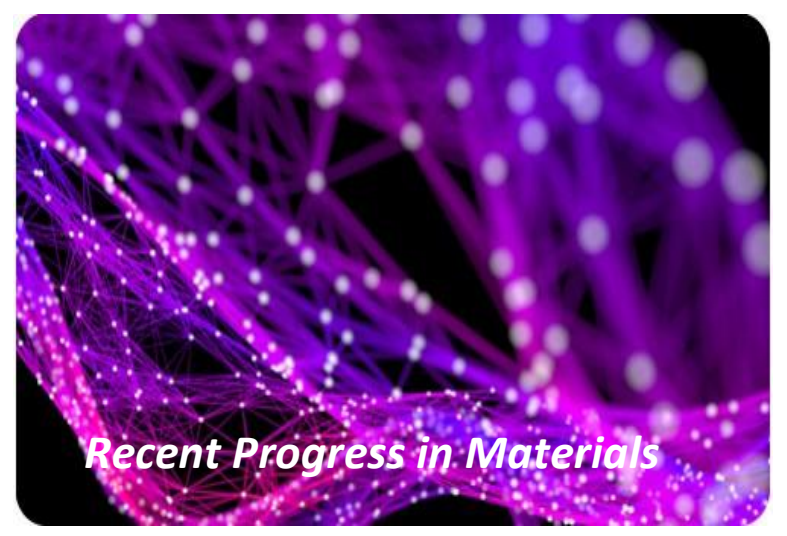

Enjoy Recent Progress in Materials by:

1. Submitting a manuscript

2. Joining in volunteer reviewer bank

3. Joining Editorial Board

4. Guest editing a special issue

For more details, please visit:

http://www.lidsen.com/journals/rpm 